\title{
High Penetration Power Electronics Grid: Modeling and Simulation Gap Analysis
}

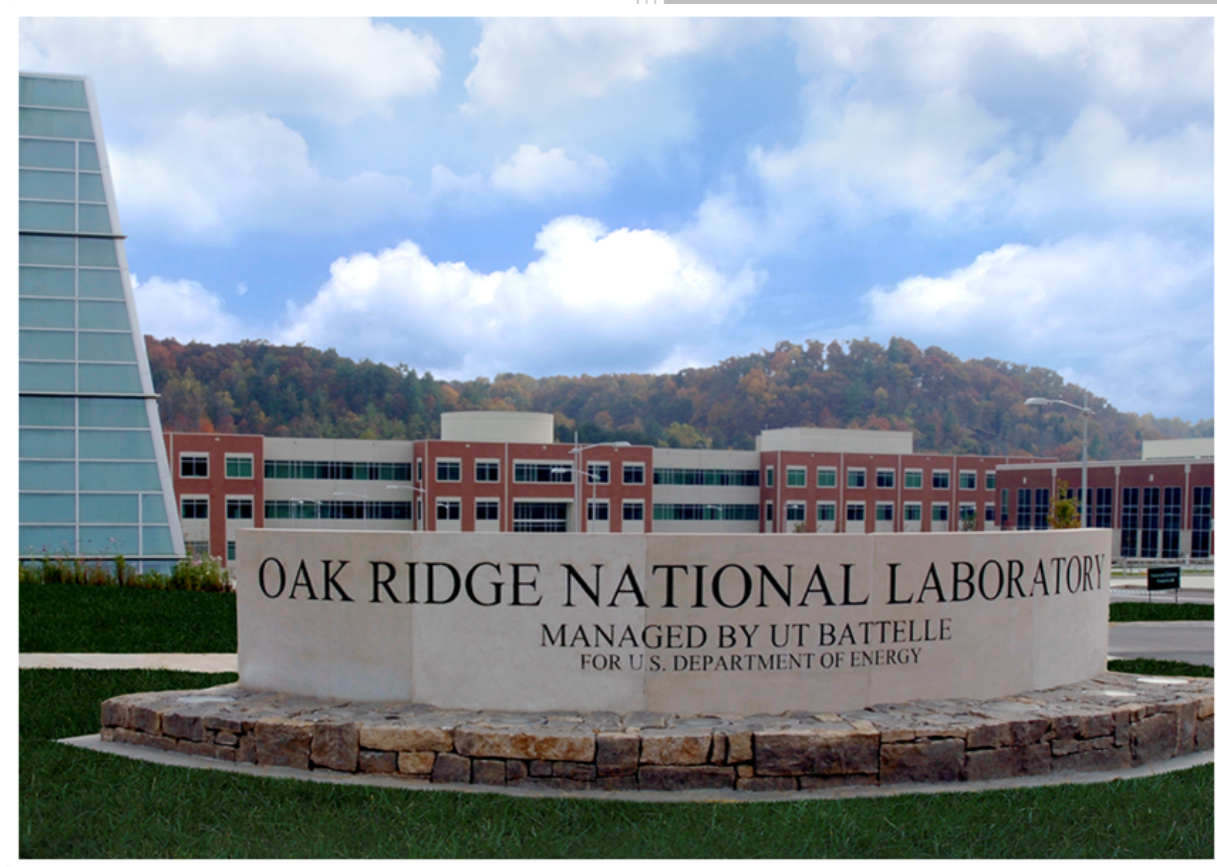

Approved for public release.

Distribution is unlimited.
Suman Debnath Marcelo Elizondo Yuan Liu Phani Marthi Wei Du

Shilpa Marti Qiuhua Huang

August 2020 


\section{DOCUMENT AVAILABILITY}

Reports produced after January 1, 1996, are generally available free via US Department of Energy (DOE) SciTech Connect.

Website www.osti.gov

Reports produced before January 1, 1996, may be purchased by members of the public from the following source:

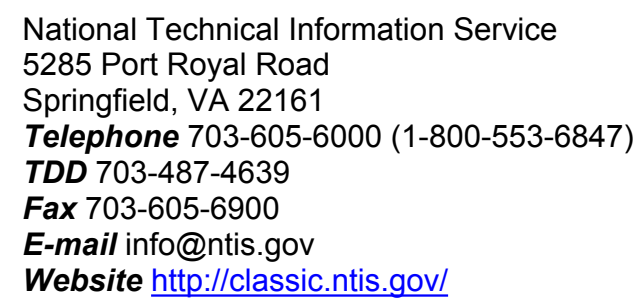

Reports are available to DOE employees, DOE contractors, Energy Technology Data Exchange representatives, and International Nuclear Information System representatives from the following source:

Office of Scientific and Technical Information

PO Box 62

Oak Ridge, TN 37831

Telephone 865-576-8401

Fax 865-576-5728

E-mail reports@osti.gov

Website http://www.osti.gov/contact.html

This report was prepared as an account of work sponsored by an agency of the United States Government. Neither the United States Government nor any agency thereof, nor any of their employees, makes any warranty, express or implied, or assumes any legal liability or responsibility for the accuracy, completeness, or usefulness of any information, apparatus, product, or process disclosed, or represents that its use would not infringe privately owned rights. Reference herein to any specific commercial product, process, or service by trade name, trademark, manufacturer, or otherwise, does not necessarily constitute or imply its endorsement, recommendation, or favoring by the United States Government or any agency thereof. The views and opinions of authors expressed herein do not necessarily state or reflect those of the United States Government or any agency thereof. 


\title{
HIGH PENETRATION POWER ELECTRONICS GRID: MODELING AND SIMULATION GAP ANALYSIS
}

\author{
Suman Debnath \\ Marcelo Elizondo \\ Yuan Liu \\ Phani Marthi \\ Wei Du \\ Shilpa Marti \\ Qiuhua Huang
}

Date Published: August 2020

Sponsored by:

U.S. Department of Energy, Office of Electricity

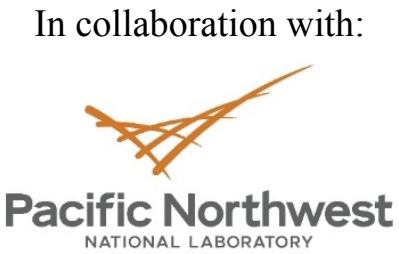

Prepared by

OAK RIDGE NATIONAL LABORATORY

Oak Ridge, TN 37831-6283

managed by

UT-BATTELLE, LLC

for the

US DEPARTMENT OF ENERGY

under contract DE-AC05-00OR22725 



\section{CONTENTS}

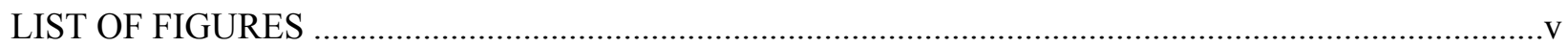

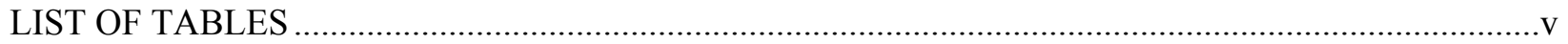

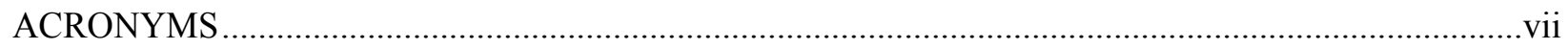

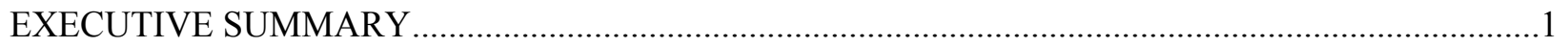

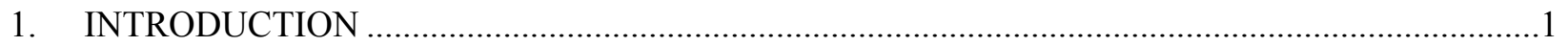

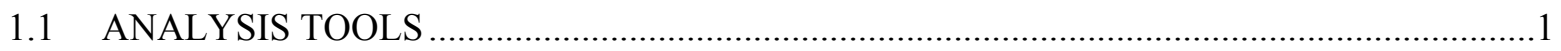

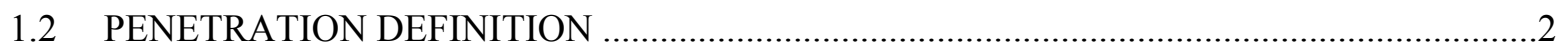

1.3 LITERATURE OVERVIEW OF STUDYING HIGH PENETRATION POWER

ELECTRONICS IN GRIDS

1.3.1 Dynamic Simulations (Component/EMT/TS) ......................................................

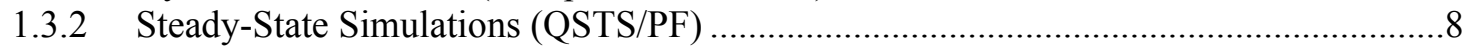

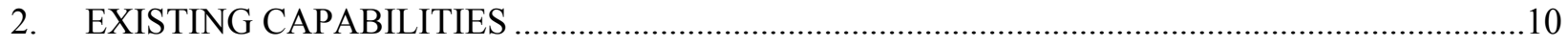

2.1 COMPONENT SIMULATION TOOLS (OFFLINE/REAL-TIME) ...................................... 10

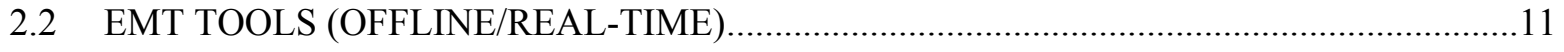

2.3 TS SIMULATION TOOLS (OFFLINE/REAL-TIME) ….....................................................

2.4 POWER FLOW SIMULATION TOOLS (OFFLINE/REAL-TIME) .....................................14

2.5 QSTS SIMULATION TOOLS (OFFLINE/REAL-TIME) …...............................................14

2.6 HARDWARE-IN-THE-LOOP SIMULATIONS …..............................................................

3. SCENARIOS, EVENTS DESCRIPTION, FUTURE GRID REQUIREMENTS, AND

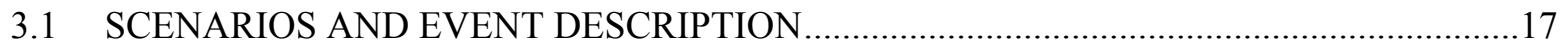

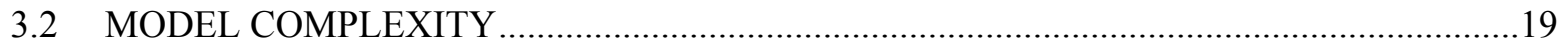

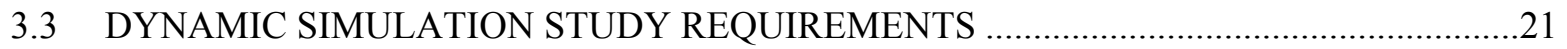

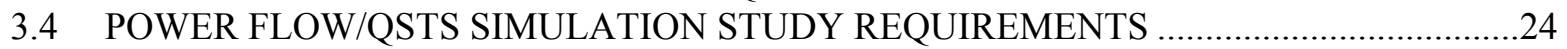

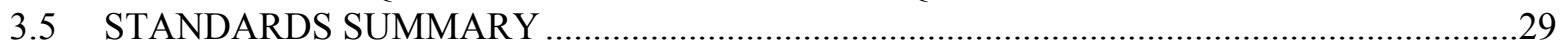

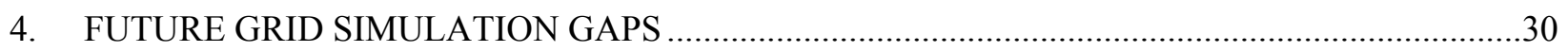

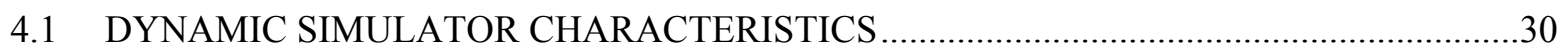

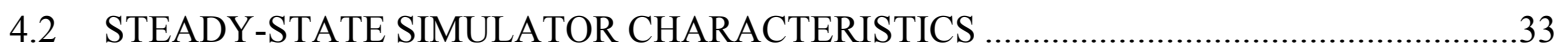

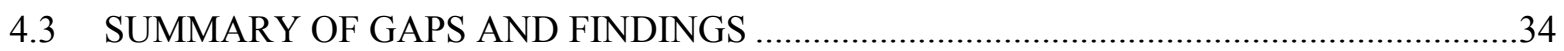

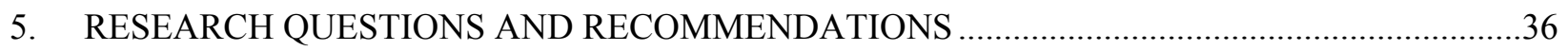

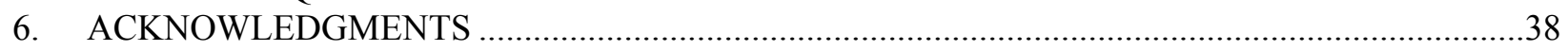

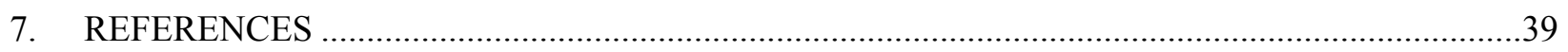

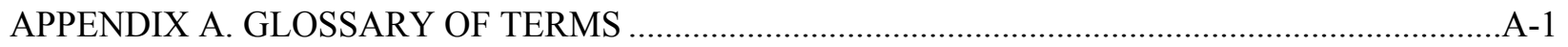





\section{LIST OF FIGURES}

Figure ES-1. Methodology to identify gaps in existing tools to simulate high penetration of power

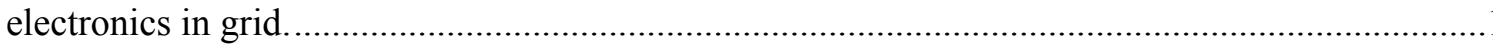

Figure ES-2. Analysis tool characterization and some of the studies performed using the tools.................2

Figure ES-3. Simple ac grid network with power electronics. ...............................................................

Figure ES-4. State estimation method for studying future scenarios of grid. .........................................17

Figure ES-5. Evolution of Load and Distributed Generation Models. ...................................................20

Figure ES-6. WECC generic renewable dynamic models evolution......................................................21

Figure ES-7. Characteristics of existing dynamic simulators (Current) and the required characteristics in future dynamic simulators (Future).................................................................

Figure ES-8. Characteristics of existing dynamic real-time simulators (Current) and the required characteristics in future dynamic real-time simulators (Future).

Figure ES-9. Characteristics of existing steady-state simulators (Current) and the required characteristics in future steady-state simulators (Future).

Figure ES-10. Characteristics of existing QSTS real-time simulators (Current) and the required characteristics in future QSTS real-time simulators (Future).

Figure ES-11. Summary of gaps in simulators to simulate grids with high penetration of power electronics.

\section{LIST OF TABLES}

Table ES-1. Summary of studies on US grids with high penetration of power electronics that used

TS simulation tools

Table ES-2. Summary of studies on US grids with high penetration of power electronics that used

EMT simulation tools. 7

Table ES-3. Summary of studies using steady-state simulation tools. .................................................10

Table ES-4. Characterization of the existing dynamic simulators........................................................13

Table ES-5. Characterization of the existing real-time dynamic simulators. .........................................14

Table ES-6. Characterization of the existing steady-state simulators.....................................................15

Table ES-7. Characterization of the existing steady-state simulators....................................................15

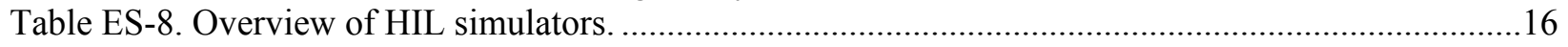

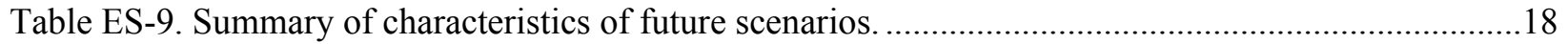

Table ES-10. Summary of dynamic study requirements in future grids...............................................23

Table ES-11. Summary of power flow study requirements in future grids. ..........................................25

Table ES-12. Summary of QSTS study requirements in future grids....................................................26

Table ES-13. Summary of characteristics of operations and studies in future scenarios. ........................27

Table ES-14. Summary of standards applicable to future grids. ...........................................................29 



\section{ACRONYMS}

$\begin{array}{ll}\text { AEMO } & \text { Australian Energy Market Operator } \\ \text { ATP } & \text { Alternative Transient Program } \\ \text { AVR } & \text { automatic voltage regulator } \\ \text { CAISO } & \text { California Independent System Operator } \\ \text { CMPLDW } & \text { composite load model } \\ \text { DER } & \text { distributed energy resources } \\ \text { EI } & \text { Eastern Interconnection } \\ \text { EMS } & \text { energy management system } \\ \text { EMT } & \text { electromagnetic transient } \\ \text { EMTP } & \text { ElectroMagnetic Transient Program } \\ \text { ERCOT } & \text { Electric Reliability Council of Texas } \\ \text { ETAP } & \text { Electrical Transient and Analysis Program } \\ \text { FACTS } & \text { flexible alternating current transmission systems } \\ \text { FPGA } & \text { field programmable gated array } \\ \text { GPU } & \text { graphic processing unit } \\ \text { HIL } & \text { hardware-in-the-loop } \\ \text { HMI } & \text { human machine interface } \\ \text { HVdc } & \text { high-voltage direct current } \\ \text { IEEE } & \text { Institute of Electrical and Electronics Engineers } \\ \text { ISO } & \text { Independent System Operator } \\ \text { MISO } & \text { Midcontinent ISO } \\ \text { MTdc } & \text { multiterminal direct current } \\ \text { NE-ISO } & \text { New England Independent System Operator } \\ \text { NERC } & \text { North American Electric Reliability Corporation } \\ \text { OpenDSS } & \text { Open Distribution System Simulator } \\ \text { ORNL } & \text { Oak Ridge National Laboratory } \\ \text { PE } & \text { power electronics } \\ \text { PF } & \text { power flow } \\ \text { PHIL } & \text { power hardware-in-the-loop } \\ \text { PNNL } & \text { Pacific Northwest National Laboratory } \\ \text { PSCAD } & \text { Power System Computer Aided Design } \\ \text { PSLF } & \text { Positive Sequence Load Flow } \\ \text { PSS } ® E & \text { Power System Simulator for Engineering } \\ \text { PV } & \text { photovoltaic } \\ \text { QSTS } & \text { quasistatic time series } \\ \text { RSCAD } & \text { real-time digital Simulator Computer Aided Design } \\ \text { SCR } & \text { short circuit ratio } \\ \text { SPP } & \text { Southwest Power Pool } \\ \text { SPS } & \text { SimPowerSystems } \\ \text { SSPS } & \text { solid-state power substation } \\ \text { SSSC } & \text { static synchronous series compensators } \\ \text { STATCOM } & \text { stationary compensator } \\ \text { T\&D } & \text { transmission and distribution } \\ \text { TS } & \text { transient stability } \\ \text { VSC } & \text { voltage-source converter } \\ \text { WECC } & \text { Western Electricity Coordinating Council } \\ \text { WI } & \text { Western Interconnection } \\ & \end{array}$





\section{EXECUTIVE SUMMARY}

Increased penetration of power electronics in the grid is happening through development of high-power drives (like in Type 3 or 4 wind turbines, industrial drives, etc.), high-voltage direct current (HVdc) systems, flexible alternating current transmission systems (FACTS), energy storage systems (ESSs), inverter-based renewables like solar and wind, electric vehicle chargers, and other technologies. Ongoing research and development in new power electronic technologies including, but not limited to, solid-state power substations (SSPS), extreme fast charging (XFC), solid-state transformers, and multi-port power electronics that integrate multiple sources/loads will further increase penetration levels. To ensure stakeholders can integrate high penetration of power electronic technologies safely and reliably requires tools and methods to assess and evaluate their impact on the grid.

Objectives: This report surveys, assesses, and analyzes commercially available and open-source tools that can support the assessment and evaluation of power electronics in future grids with high penetration levels. The study includes aspects that range from power flow analysis to dynamics evaluation (including hardware-in-the-loop - HIL testing) for such systems. The challenges and gaps associated with the current generation of toolsets available to assess the technical impact of introducing high penetration of power electronics are reported. The method is summarized in Figure ES-1.

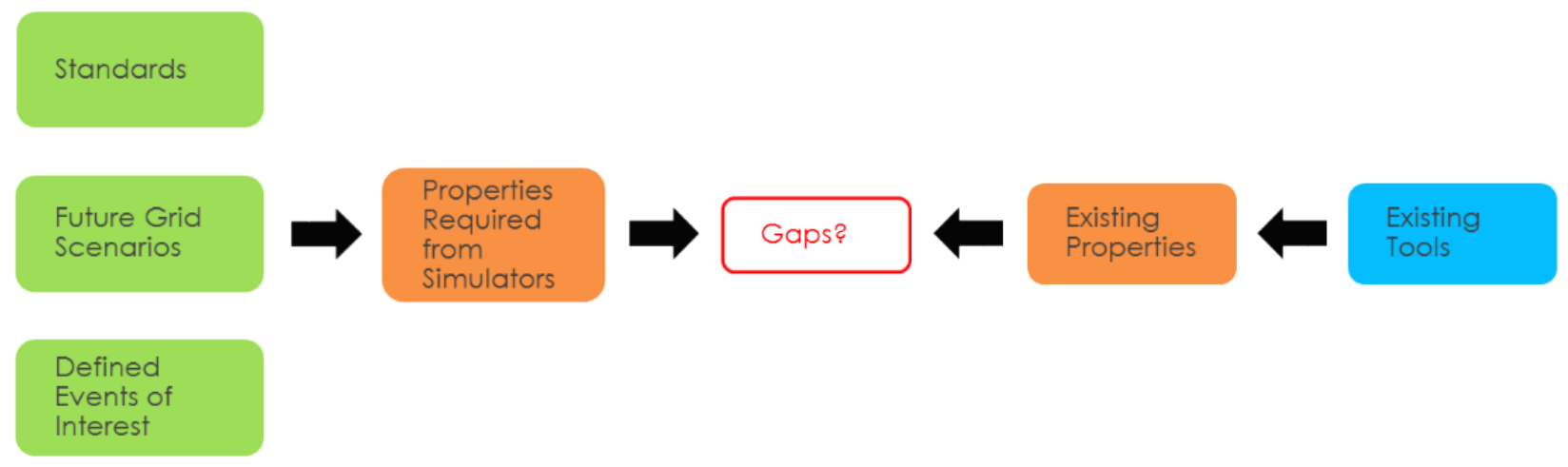

Figure ES-1. Methodology to identify gaps in existing tools to simulate high penetration of power electronics in grid.

Value Proposition: The contents of this report can enable decision makers and investors to make informed decisions about future investments in improving simulation tools. This work quantifies the gaps in assessing future grids and the corresponding improvements required in future simulation tools.

\section{INTRODUCTION}

\subsection{ANALYSIS TOOLS}

To study the characteristics of the grid or a component in the grid and its operations, models of the corresponding characteristics need to be developed. These models are then processed and simulated by a tool to generate the characteristics of the grid or the component in the grid and its operations. The tools available to study the grid or a component in the grid in an offline simulation have been characterized based on the time step used to simulate the model. The tools include component/electromagnetic transient (EMT) simulators, electromechanical transients or transient stability (TS) simulators, quasi-static time series (QSTS) simulators, and power flow (PF) or short circuit simulators. Some of the studies performed using these tools and the corresponding time steps used are shown in Figure ES-2. 


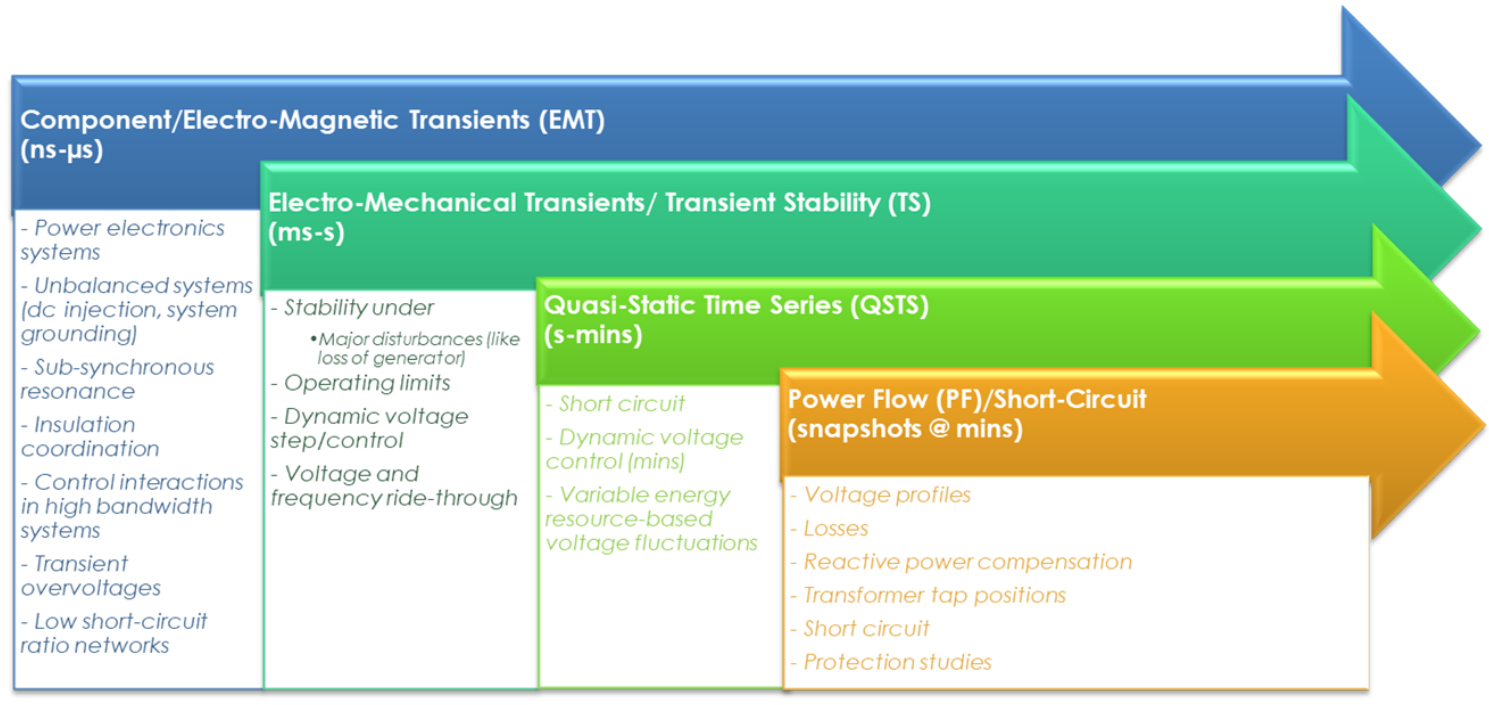

Figure ES-2. Analysis tool characterization and some of the studies performed using the tools.

The model simulated in a tool is developed by the user and represents the characteristics of the system being analyzed. For example, in an EMT simulation of the dynamics of the power grid, the user identifies the individual components of the power grid from the model library and designates their connections. The user can also develop custom models representing the EMT dynamics of individual components. Ultimately, models represent the EMT dynamics of individual components in the form of differential algebraic equations (DAEs) or algebraic equations. Once the model is generated, the EMT simulator processes the model (i.e., the DAEs) by discretizing and linearizing the model, and solving the resultant linear system of equations at every time step. A similar process is followed in other simulators.

Corresponding software and hardware perform real-time simulation of component/EMT models, TS models, and QSTS models. Some of these software and hardware have been used to perform hardware-inthe-loop (HIL) simulations.

\subsection{PENETRATION DEFINITION}

To begin the discussion on high penetration of power electronics, one of the critical factors is the definition of the term "penetration of power electronics." In this report, the penetration of power electronics is not limited to the integration of variable renewables resources, but it also includes the power electronics that are expected to be present in variable-speed drives connecting to traditional synchronous generators, power flow controllers, energy storage devices, loads, and other forthcoming power electronic technologies (e.g., solid-state power substations). "Penetration of power electronics" can be defined as the weighted average of power passing through power electronics in the grid. This definition provides an indication of the number of power electronics equipment present in the grid, the rating of the power electronics equipment, and the proximity of power electronics from each other. Although the number and rating of power electronics are inherently identified in the weighted average, their proximity can be identified by calculating the penetration of power electronics in local regions separately. The weighted average is the ratio of the summation of the power passing through power electronics at each bus to the summation of generation, load, and branch power that is weighted by the presence of power electronics. In this formulation, the power terms are absolute values and are considered greater than zero. A simple system is shown in Figure ES-3. 


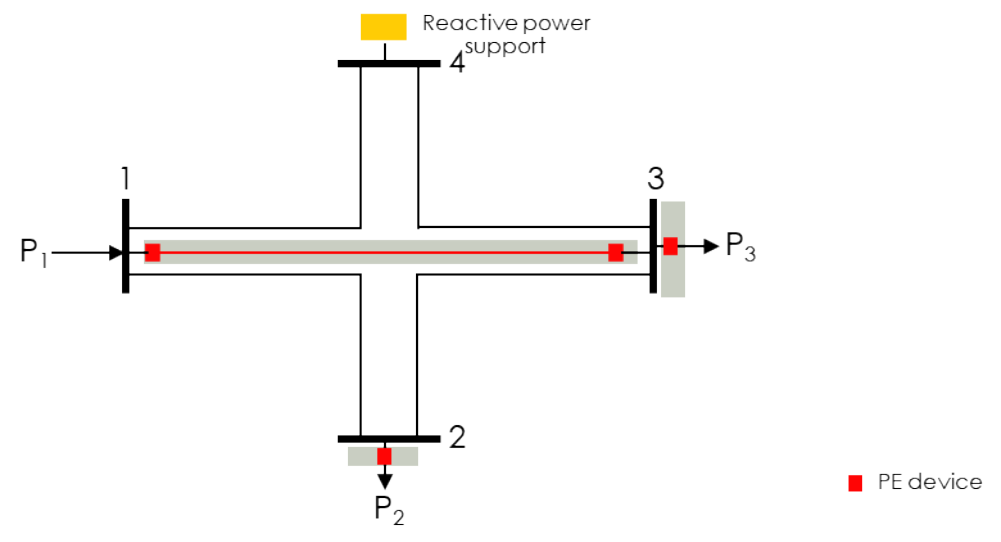

Figure ES-3. Simple ac grid network with power electronics.

The corresponding penetration of power electronics is given by

$$
\begin{aligned}
& \mathrm{P}_{\%}^{\mathrm{PE}}=\frac{\text { Summation of power flowing through power electronics at each bus }}{\text { Summation of generation, load, and branch powers (weighted for PE buses) }} \\
& =\frac{\overbrace{\left(P_{13}\right)+\left(P_{2}\right)+\left(P_{13}+P_{3}\right)}^{\text {Bus-1 Bus-2 }}}{\left(P_{1}\right)+\left(P_{2}+P_{3}\right)+\left(2 P_{13}+P_{14}+P_{12}+P_{23}+P_{34}\right)}
\end{aligned}
$$

An approximation of the formula is provided below:

$$
\begin{aligned}
& \mathrm{P}_{\%}^{\mathrm{PE}}=\lambda_{\mathrm{g}} \frac{\text { Generation PE }}{\text { Total generation }}+\lambda_{\mathrm{l}} \frac{\text { Load PE }}{\text { Total load }}+\lambda_{\text {pfc }} \frac{\text { PFC PE weighed power }}{\text { Total weighted power through branches }} \\
& =\lambda_{\mathrm{g}} \frac{0}{P_{1}}+\lambda_{\mathrm{l}} \frac{\left(P_{2}+P_{3}\right)}{\left(P_{2}+P_{3}\right)}+\lambda_{\mathrm{pfc}} \frac{\left(2 P_{13}\right)}{\left(2 P_{13}+P_{14}+P_{12}+P_{23}+P_{34}\right)}
\end{aligned}
$$

This formula is a valid approximation if the total generation, total load, and total weighted power through branches are similar. This is, in general, a valid argument in the power grid. "Penetration of power electronics" can also be defined as the weighted average of power electronics in generation, load, and power flow controllers. This definition is simpler to calculate for transmission planners, planning coordinators, reliability coordinators, generator owners, and generator operators, among others.

In this report, future scenarios are evaluated for $0-20 \%, 20-50 \%$, and $50-100 \%$ penetration of power electronics in the grid. The corresponding scenarios are designated as traditional, intermediate, and longterm scenarios. These classifications are based on the penetration of power electronics expected in the grid in the near-term (2-5 years), mid-term (5-10 years), and long-term ( $>10$ years), respectively. Penetration percentages are based on projections for the amount of renewables integration in the grid, power electronics in loads, and power flow controllers introduced. The penetrations are defined based on the formulae above using rated power capacities. The definition can be extended to grid operations, where the instantaneous penetration of power electronics can be calculated based on operating power conditions (rather than rated power of components). 


\subsection{LITERATURE OVERVIEW OF STUDYING HIGH PENETRATION POWER ELECTRONICS IN GRIDS}

Several workshops have been conducted in United States and Europe on the future grids with high penetration of power electronics [1, 2, 3, 4]. In these workshops, an explicit definition of power electronics penetration was not provided, and discussion primarily focused on the integration of renewable resources. The challenges presented in these workshops are included in the literature reviewed below.

\subsubsection{Dynamic Simulations (Component/EMT/TS)}

In this section, some of the studies performed in the past 5 years on grids with increased penetration of power electronics using dynamic simulations are discussed. The challenges involved in grid with high penetration of power electronics and in performing such studies are briefly surveyed.

Several independent system operators (ISOs) in United States are performing or have performed stability analysis on grids with high penetration of power electronics-based resources. Similar studies have been performed by utilities or grid operators worldwide. The studies that used TS simulation tools are first discussed in this section. One of the studies performed by Midcontinent ISO (MISO) on high penetration of renewables in low loading scenarios identified instability in the grid upon loss of generation. This study indicated stability may be improved by using HVdc links to transport renewables, which is less expensive compared to the traditional upgrades needed in the alternating current (ac) grid [5]. A study performed by Southwest Power Pool (SPP) assessed stability limitations with increased penetration of wind power plants [6]. Short circuit ratio (SCR) analysis has also been performed in the study to identify strengths at the locations of integrating generation resources. This study identified critical clearing times and SCRs in different regions to understand the stability limitations. Based on the simulations in the study, a few unstable operating conditions have been identified, and advanced control methods were recommended for the inverter-based generations. A study performed at California Independent System Operator (CAISO) [7] demonstrated improved transient voltage performance from inverter-based generation through improved damping and faster voltage recovery. Concerns have been raised in the study for high penetration of inverters without ride through capabilities that limit recovery upon events. Another observation is the prevalence of high voltages with large penetration of distributed solar generation. The influence of increased penetration of wind and solar in Western Interconnection (WI) has been studied in $[8,9]$. These studies have identified the requirements for fast frequency response and transmission upgrades that may assist in TS of the WI. Similar studies have also been considered with high penetration of solar in Eastern Interconnection (EI) [10, 11] and of wind in EI [12]. These studies identified the inter-area oscillations in the interconnection, damping requirements in the interconnection, and fast frequency support (through inertial and governor control) needed in the interconnection. The frequency response trends in the three US interconnections of EI, WI, and Texas Interconnection has been studied with increased penetration of solar energy [13]. Several studies have been performed on the grid in Europe with increased penetration of power electronics. For example, a study was performed on the grid in Ireland to identify the challenges introduced in protection systems at higher penetration of renewables with increased rate of change of frequency [14]. Other examples were included in the MIGRATE [1] and RESERVE projects [2], which study various challenges with a power electronicsdominated grid in Europe. These studies used TS and EMT simulation tools. In addition to the study of increased penetration of renewables, studies were also performed on HVdc systems $[15,16,17]$, to name a few. The studies are summarized in Table ES-1. 
Table ES-1. Summary of studies on US grids with high penetration of power electronics that used TS simulation tools.

\begin{tabular}{|c|c|c|c|}
\hline $\begin{array}{l}\text { Organization/ } \\
\text { Reference }\end{array}$ & Scenarios and Studies & Challenges Identified & Improvements/Recommendations \\
\hline MISO [5] & $\begin{array}{l}\text { High penetration of } \\
\text { renewables in low } \\
\text { loading scenarios. }\end{array}$ & $\begin{array}{l}\text { Instability in the grid upon loss } \\
\text { of generation. }\end{array}$ & $\begin{array}{l}\text { Stability maybe improved by using } \\
\text { HVdc links to transport renewables. }\end{array}$ \\
\hline SPP [6] & $\begin{array}{l}\text { To assess stability } \\
\text { limitations with } \\
\text { increased penetration } \\
\text { of wind power plants. } \\
\text { SCR analysis to } \\
\text { identify strengths at the } \\
\text { locations of integrating } \\
\text { generation resources. }\end{array}$ & $\begin{array}{l}\text { Identified critical clearing } \\
\text { times and SCRs in different } \\
\text { regions causing a few unstable } \\
\text { operating conditions. }\end{array}$ & $\begin{array}{l}\text { Advanced control methods were } \\
\text { recommended for the inverter- } \\
\text { based generations. }\end{array}$ \\
\hline CAISO [7] & $\begin{array}{l}\text { Inverter-based } \\
\text { generation through } \\
\text { improved damping and } \\
\text { faster voltage recovery. }\end{array}$ & $\begin{array}{l}\text { Concerns for high penetration } \\
\text { of inverters without ride } \\
\text { through capabilities that limit } \\
\text { recovery upon events were } \\
\text { raised. Prevalence of high } \\
\text { voltages with increased } \\
\text { penetration of distributed solar } \\
\text { generation. }\end{array}$ & $\begin{array}{l}\text { Improved transient voltage } \\
\text { performance was indicated. }\end{array}$ \\
\hline WI study in $[8,9]$ & $\begin{array}{l}\text { Impact of increased } \\
\text { penetration of wind } \\
\text { and solar. }\end{array}$ & TS challenges being resolved. & $\begin{array}{l}\text { Identified the requirements for fast } \\
\text { frequency response and } \\
\text { transmission upgrades that may } \\
\text { assist in TS of the WI. }\end{array}$ \\
\hline $\begin{array}{l}\text { EI study in }[10, \\
11,12]\end{array}$ & $\begin{array}{l}\text { Impact of increased } \\
\text { penetration of wind } \\
\text { and solar. }\end{array}$ & $\begin{array}{l}\text { Identified the inter-area } \\
\text { oscillations in the } \\
\text { interconnection. }\end{array}$ & $\begin{array}{l}\text { Identified damping requirements in } \\
\text { the interconnection, fast frequency } \\
\text { support (through inertial and } \\
\text { governor control) needed in the } \\
\text { interconnection. }\end{array}$ \\
\hline
\end{tabular}

There has been an increasing trend toward using EMT simulation tools to perform stability studies on larger areas of the grid with increased penetration of renewables. For example, the North American Electric Reliability Corporation (NERC) and the Western Electricity Coordinating Council (WECC) study on the fault response of the photovoltaic (PV) plants or distributed energy resources (DERs) in California during fire incidents $[18,19,20]$ have identified the need for higher fidelity models of PV and wind plants and the grid. The challenge with the existing models and simulation methods is the inability to replicate the behavior of PV and wind plants upon unbalanced faults that affect the reliability of the grid. The study also indicated the increasing need for EMT simulations. EMT simulations of PV plants and grids has been performed in one of the studies by Sandia National Laboratories to assess and identify the influence of negative-sequence injections during unbalanced faults on the protection relays [21]. These studies also discuss the stability challenges in a weak grid with inverter-based resources and different SCR metrics suitable in such conditions. Studies on EMT simulation of (i) PV plants and grids during faults $[22,23]$ and (ii) DERs interactions with bulk power system by New England Independent System Operator (NE-ISO) [24] are ongoing. The NE-ISO study is researching the stability with increased penetration of DERs in low load regions due to interactions between controllers, weak grids, trip during grid events, among others. The projects in $[22,23]$ are exploring advanced modeling of PV plants and grid simulation methods that can aid in studying the stability and reliability of higher penetration of PV plants or DERs in the grid. 
An EMT simulation of the grid in the Texas Pan Handle region with high penetration of wind resources was performed by Electric Reliability Council of Texas (ERCOT). The goal of the study was to assess the effect on stability of the grid with increased penetration of power electronics (PE)-based generation [25]. A similar study was also performed by Australian Energy Market Operator (AEMO) for the increased penetration of wind in Southern Australia [26]. The ERCOT and AEMO studies were performed to identify the stability of the grid and the protection related challenges with increased penetration of wind. EMT simulations were used in these studies to understand subsynchronous control interactions that are not observed in the traditional models. Also, they have been used to identify the minimum non-power electronics generation using synchronous machines needed to maintain stability of the grid. Finally, they have identified the need to develop SCR metrics to quantify the strength of the grid with high penetration of inverter-based resources. The EMT simulation of wind power plants in a small region of 130 buses and 7 wind power plants was also performed by SPP [6]. The study considered a local region that is characterized by low critical clearing time and SCR. The study's results showed a close correlation between the control system in wind power plants and the stability of the region's grid. Other EMT studies are being performed to study control interactions in wind power plants [27].

Several other EMT simulation studies have been performed for other power electronics driven resources. One of the studies considers the benefits of introducing a higher penetration of solid-state power substations like HVdc systems. An Oak Ridge National Laboratory (ORNL) and Pacific Northwest National Laboratory (PNNL) [28, 29] study considered different configurations of HVdc systems based on voltage-source converters (VSCs) and line-commuted converters (LCCs) connecting US interconnections. One configuration is a VSC based multiterminal direct current (MTdc) systems connecting EI, ERCOT, and Western Interconnection (WI) grids. The VSC-based MTdc system can use higher bandwidth control systems compared to the traditional LCC-based HVdc systems. EMT simulations were used in this study to research the advanced high-bandwidth control methods that may be introduced in the VSCs and MTdc systems to provide fast frequency response sharing across interconnections and dynamic voltage support locally. The traditional TS simulations are inadequate to identify the stability of high-bandwidth control methods because of the inadequate fidelity in the models. Hybrid EMT-TS simulations were also explored in the study. Other EMT simulation studies were performed by ORNL to study the impact of dynamic wireless charging and the corresponding solid-state power substation (SSPS) requirements in the grid [30], benefits of multiport power electronics integrating several resources (like PV, energy storage) to the grid [31], challenges associated with extreme fast charging and DERs, and microgrids [32]. Several other literature studies have considered EMT simulations to study increased penetration of power electronics in grids [33,34]. EMT simulation studies are summarized in Table ES-2. 
Table ES-2. Summary of studies on US grids with high penetration of power electronics that used EMT simulation tools.

\begin{tabular}{|c|c|c|c|}
\hline Organization/Reference & Scenarios and Studies & Challenges Identified & Outcomes \\
\hline $\begin{array}{l}\text { NERC and WECC }[18, \\
19,20]\end{array}$ & $\begin{array}{l}\text { Fault response of the PV } \\
\text { plants or DERs in } \\
\text { California during the fire } \\
\text { incidents. }\end{array}$ & $\begin{array}{l}\text { Challenge in the existing } \\
\text { models and simulation } \\
\text { methods is the inability to } \\
\text { replicate the behavior of } \\
\text { PV and wind plants upon } \\
\text { unbalanced faults. }\end{array}$ & $\begin{array}{l}\text { Identified the need for higher } \\
\text { fidelity models of PV and } \\
\text { wind plants and grid. Also } \\
\text { indicated the increasing need } \\
\text { for using EMT simulations. }\end{array}$ \\
\hline $\begin{array}{l}\text { Sandia National } \\
\text { Laboratories [21] }\end{array}$ & $\begin{array}{l}\text { The impact of negative- } \\
\text { sequence injections } \\
\text { during unbalanced faults } \\
\text { on the protection relays. }\end{array}$ & $\begin{array}{l}\text { The stability challenges in } \\
\text { a weak grid with inverter- } \\
\text { based resources. }\end{array}$ & $\begin{array}{l}\text { Different SCR metrics that } \\
\text { are suitable to evaluate these } \\
\text { conditions. }\end{array}$ \\
\hline Study in $[22,23]$ & $\begin{array}{l}\text { Study of PV plants and } \\
\text { grids during faults. }\end{array}$ & $\begin{array}{l}\text { Stability and reliability of } \\
\text { high penetration of PV } \\
\text { plants or DERs in grid. }\end{array}$ & $\begin{array}{l}\text { Ongoing studies that are } \\
\text { expected to develop } \\
\text { advanced models of PV } \\
\text { plants and grid simulation } \\
\text { methods using existing tools. }\end{array}$ \\
\hline NE-ISO [24] & $\begin{array}{l}\text { DERs interactions with } \\
\text { bulk power system. }\end{array}$ & $\begin{array}{l}\text { Researching the stability } \\
\text { with increased penetration } \\
\text { of DERs in low load } \\
\text { regions due to interactions } \\
\text { between controllers, weak } \\
\text { grids, trip during grid } \\
\text { events, among others. }\end{array}$ & Ongoing study. \\
\hline $\begin{array}{l}\text { ERCOT [25] and } \\
\text { AEMO [26] }\end{array}$ & $\begin{array}{l}\text { Assess the impact on } \\
\text { stability of the grid with } \\
\text { increased penetration of } \\
\text { power electronics-based } \\
\text { wind generation in the } \\
\text { Pan Handle region } \\
\text { (ERCOT study). } \\
\text { Increased penetration of } \\
\text { wind in Southern } \\
\text { Australia (AEMO study). }\end{array}$ & $\begin{array}{l}\text { Stability of the grid and the } \\
\text { protection related } \\
\text { challenges with increased } \\
\text { penetration of wind. }\end{array}$ & $\begin{array}{l}\text { EMT simulations have been } \\
\text { used to understand } \\
\text { subsynchronous control } \\
\text { interactions that are not } \\
\text { observed in the traditional } \\
\text { models. } \\
\text { Identified the minimum non- } \\
\text { power electronics generation } \\
\text { using synchronous machines } \\
\text { needed to maintain stability } \\
\text { of the grid. } \\
\text { Identified the need to develop } \\
\text { SCR metrics to quantify the } \\
\text { strength of the grid with high } \\
\text { penetration of inverter-based } \\
\text { resources. }\end{array}$ \\
\hline SPP [6] & $\begin{array}{l}\text { Simulation of wind power } \\
\text { plants in a small region of } \\
130 \text { buses and } 7 \text { wind } \\
\text { power plants was } \\
\text { performed. }\end{array}$ & $\begin{array}{l}\text { Stability of the local region } \\
\text { with high penetration of } \\
\text { wind. }\end{array}$ & $\begin{array}{l}\text { A close correlation between } \\
\text { the control system in wind } \\
\text { power plants and the stability } \\
\text { of the region's grid was } \\
\text { observed. }\end{array}$ \\
\hline
\end{tabular}


Table ES-2. Summary of studies on US grids with high penetration of power electronics that used EMT simulation tools (continued).

\begin{tabular}{|c|c|c|c|}
\hline Organization/Reference & Scenarios and Studies & Challenges Identified & Outcomes \\
\hline ORNL, PNNL [28, 29] & $\begin{array}{l}\text { Different configurations } \\
\text { of HVdc systems based } \\
\text { on VSCs and LCCs } \\
\text { connecting US } \\
\text { interconnections have } \\
\text { been researched. }\end{array}$ & $\begin{array}{l}\text { Traditional TS simulations } \\
\text { are inadequate to identify } \\
\text { the stability of high- } \\
\text { bandwidth control methods } \\
\text { due to the inadequate } \\
\text { fidelity in the models. }\end{array}$ & $\begin{array}{l}\text { EMT simulations have been } \\
\text { used to research the advanced } \\
\text { high-bandwidth control } \\
\text { methods that may be } \\
\text { introduced in the VSCs and } \\
\text { MTdc systems to provide fast } \\
\text { frequency response sharing } \\
\text { across interconnections and } \\
\text { dynamic voltage support } \\
\text { locally. } \\
\text { Hybrid EMT-TS simulations } \\
\text { have also been explored in } \\
\text { the study. }\end{array}$ \\
\hline
\end{tabular}

TS simulation tools may not provide accurate representation of the dynamics of grids with increased penetration of power electronics [25]. The challenges in simulating accurately the grids with increased penetration of power electronics using TS simulation tools arise from low SCR, high bandwidth control systems, control interactions, and sensitivity of power electronics to external disturbances, to name a few. Challenges in simulating grids with TS simulation tools lead to the increased use of EMT simulation tools. One of the concerns raised by the aforementioned studies include the increased computation burden imposed by EMT simulations and the ability to collect data to develop high-fidelity models. For example, the time taken to simulate the EMT simulation models of the South Australian grid in an AEMO study for a $20 \mathrm{~s}$ duration of simulation is $3 \mathrm{~h}$. Similarly, the time taken to simulate the EMT simulation models of the Texas Pan Handle region in ERCOT study for a $30 \mathrm{~s}$ duration of simulation is $2 \mathrm{~h}$.

\subsubsection{Steady-State Simulations (QSTS/PF)}

Studies performed on grids with increased penetration of power electronics using steady-state simulations during the past 5 years are discussed in this section. The challenges involved in grids with high penetration of power electronics and in performing such studies are briefly surveyed.

Power flow algorithms with increasing portion of de networks have not been fully developed nor widely adopted by industry. Current algorithms iterate between solutions of the ac and dc systems [35]. This method provides sufficient accuracy in analyzing current grids with few dc portions in the system.

Additionally, power flow models and data sets should capture static reactive capability of wind and solar renewable generation [36]. Currently WECC modeling working groups are creating data sets and testing models to capture high penetration of DER [37]; power flow model structure and explicit representation of DER are being considered.

A recent trend also considers cosimulations between transmission and distribution (T\&D) models [38]. To achieve higher accuracy, the cosimulation involves iterations between solutions in the transmission model and the distribution models. Since there is increasing penetration of DER and the distribution networks could become much dynamically active in the future, large scale T\&D cosimulations will be needed, which would require improvement in simulation methods and algorithms. 
NERC [39] currently requires transmission operators and reliability coordinators to perform a contingency analysis every 30 min using real-time information. The contingency analysis is currently based on power flow solutions, which means that transmission operators and reliability coordination need to solve algorithms and analyze results of many contingencies within a short time. The requirements are further exacerbated with increased penetration of power electronics that may require T\&D power flow simulations or ac-dc power flow simulations.

Some of the QSTS simulation experiences to study high penetration of power electronics-based solar generation is presented below. Most of the QSTS modeling efforts have been concentrated at the distribution level [40] to study behavior of distribution feeders for high penetration of solar distributed generation, as well as for studying the effect of demand-response programs with multistate load models [41]. In addition to the QSTS studies for distribution, there has been a trend of applying QSTS toward studying larger geographic areas, beyond distribution, to include subtransmission. There have also been efforts to develop HIL QSTS and adaptive simulations. With the increase in renewable variable generation in larger geographic areas, these initial trends may become a required modeling practice. PNNL collaborated with Duke Energy to identify the need for QSTS at subtransmission level to evaluate the impact of new power flow patterns propagating from distribution to subtransmission as solar photovoltaic generation increases [42]. As part of a follow up effort, PNNL developed a new subtransmission and distribution cosimulation tool and control strategy called the Coordinated Real-Time Sub-Transmission Volt-Var Control Tool (CReST-VCT). CReST-VCT was tested on a Duke Energy Carolina system to demonstrate the effect of the voltage control capability by dispatching DERs' reactive power support [43]. The algorithm runs every 5 min solving an ac optimal power flow problem and was tested in QSTS simulation. At the distribution level, a voltage control algorithm dispatches reactive power from DERs with the goals of meeting subtransmission service requirements and satisfying all the constraints at the distribution side. A power hardware-in-the-loop (PHIL) architecture to test the influence of volt/var controls in PV inverter on feeder voltages has been proposed [44, 45]. The architecture includes advanced PV inverters with reactive power control located at the National Renewable Energy Laboratory's Energy Systems Integration Facility, the open-source GridLAB-D distribution modeling platform supporting real-time synchronization and QSTS simulation at PNNL's Electricity Infrastructure Operations Center, and communication link between the National Renewable Energy Laboratory's PHIL simulation and PNNL's GridLAB-D distribution system model. This PHIL architecture showed the flexibility required to interconnect different facilities for slow system phenomena captured by QSTS [45].

Short circuit analysis has traditionally been performed by estimating short circuit currents based on contribution from synchronous machines and electric motors [46]. These algorithms have been used for quickly screening and studying system strength and evaluating circuit breakers as part of system planning studies. The algorithms are challenged by the fact that power electronics-based devices do not have a standard or unique way of contributing to short circuit currents [47]. Presently, the contribution from power electronics devices is dependent upon the vendor, which may consider the limitations of the semiconductor devices present, the standards, or a combination of both.

NERC recommends that transmission operators understand areas of concern with low SCR and that they establish sufficient requirements to integrate power electronics-based resources [48]. To study SCR and system strength as part of the integration of large amounts of renewable generation, the following approaches maybe applied:

- Expanded new SCR metrics derived from traditional SC studies were applied as screening methods for ERCOT [49], NERC [50], and MISO [51]. These metrics are recommended to gain a high-level understanding of the potential issues that could arise from integrating power electronics-based resources [50]. 
- Simulations with EMT models instead of using traditional short circuit algorithms were performed in AEMO, Australia [52]. NERC suggests that transmission planners may consider using EMT models after SCR screening [50].

- New algorithms and metrics have been proposed in the literature [53].

These studies may help identify solutions like dynamic compensation requirements (synchronous compensation, FACTS, HVdc) [49], [51] to strengthen the grid. For example, AEMO proposed a solution criterion for weak grid issues through establishment of a minimum requirement of online synchronous machines [52]. Other solutions strategies could include also enhancing controls of inverter-based resources [50]. The steady-state simulation studies are summarized in Table ES-3 below.

Table ES-3. Summary of studies using steady-state simulation tools.

\begin{tabular}{|c|c|c|c|}
\hline Power Flow & $\begin{array}{c}\text { Transmission and } \\
\text { Distribution (T\&D) } \\
\text { Power Flow } \\
\text { Cosimulation }\end{array}$ & QSTS & Short Circuit \\
\hline $\begin{array}{l}\text { Need for advanced } \\
\text { algorithms for high } \\
\text { penetration of dc } \\
\text { lines and networks. } \\
\text { Wind and solar plant } \\
\text { representations have } \\
\text { been developed. } \\
\text { Ongoing industry } \\
\text { development of data } \\
\text { sets and models for } \\
\text { high penetration of } \\
\text { DER. } \\
\text { NERC currently } \\
\text { requires contingency } \\
\text { analysis every } 30 \\
\text { min. }\end{array}$ & 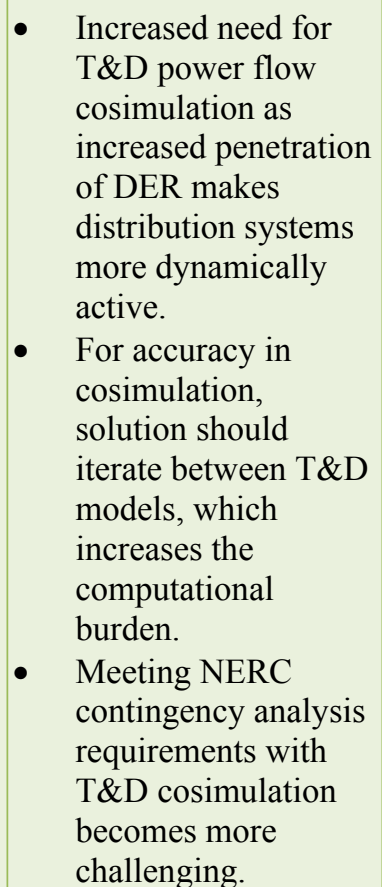 & 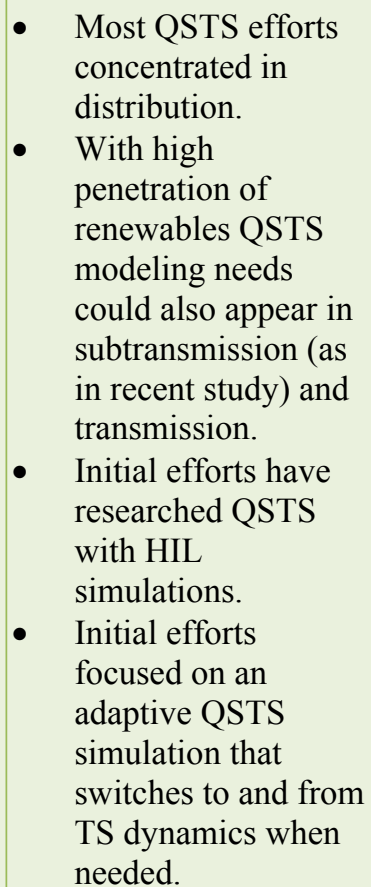 & $\begin{array}{l}\text { Algorithms for screening } \\
\text { system strength and } \\
\text { evaluating circuit breakers as } \\
\text { part of system planning. } \\
\text { Power electronics-based } \\
\text { devices do not have a } \\
\text { standard or unique way of } \\
\text { contributing to fault currents } \\
\text { (vendor dependent). } \\
\text { Expanded new SCR metrics } \\
\text { derived from traditional } \\
\text { system to gain a high-level } \\
\text { understanding. } \\
\text { EMT simulations } \\
\text { recommended. }\end{array}$ \\
\hline
\end{tabular}

\section{EXISTING CAPABILITIES}

\subsection{COMPONENT SIMULATION TOOLS (OFFLINE/REAL-TIME)}

Some of the component simulators include MATLAB/Simulink/SimPowerSystems (SPS), PSCAD, Piecewise Linear Electric Circuit Simulation (PLECS), Power electronics Simulator (PSIM), Linear Technology Simulation Program with Integrated Circuit Emphasis (LT SPICE), among others. These simulators have typically been used to simulate components like power electronics and semiconductor devices. The typical simulation of duration of components is hundreds of milliseconds to two seconds with a time step on the order of nanoseconds to microseconds. The number of states simulated is on the order of 
tens of thousands (with a maximum of 50,000 estimated), and the time taken to simulate ranges from $1 \mathrm{~min}$ to $10 \mathrm{~h}[28,29]$.

The real-time component simulators include eFPGASIM, Real-time Digital Simulator Computer Aided Design (RSCAD®), Typhoon, among others. They have the capability to simulate up to 128 switches/FPGA [54] and up to 6,000 submodules (SMs) in a modular multilevel converter (MMC) in real-time $[55,56]$. The typical time step is on the order of several hundreds of nanoseconds. The number of states per unit simulated is on the order of hundreds to thousands (with a maximum of up to 18,000 estimated) $[57,58]$. The total number of states simulated is on the order of tens of thousands (with a maximum of 25,000 estimated) [59]. Component-EMT cosimulation is feasible using eFPGASIM and eMEGASIM [60] and RSCAD ${ }^{\circledR}$ substep high-fidelity simulation [61].

\subsection{EMT TOOLS (OFFLINE/REAL-TIME)}

Some of the time domain EMT simulators include Power System Computer Aided Design (PSCAD), ElectroMagnetic Transient Program (EMTP)-RV, SPS, PSS®SINCAL, DIgSILENT PowerFactory, Electrical Transient and Analysis Program (ETAP), Alternative Transient Program (ATP), among others. These simulators have typically been used to simulate fast transients associated power electronics hardware, study insulation coordination, and perform stability analysis on smaller transmission or distribution systems that are on the order of 1,000 nodes or buses in size. The typical duration of simulation is up to $30 \mathrm{~s}$ with a time step of $1-50 \mu \mathrm{s}$. The number of states simulated is on the order of millions (with a maximum of up to 7 million estimated), and the time taken to simulate ranges from 2.25 to $5 \mathrm{~h}[25,26]$. Additionally, there are capabilities to perform hybrid EMT-TS simulation through software like E-Tran that connects PSCAD to Power System Simulator for Engineering (PSS ${ } E$ ), PSS ${ }$ SINCAL, DIgSILENT PowerFactory, and EMTP-RV, among others. The estimated number of boundary buses simulated in hybrid simulations is in the tens (with a maximum of up to 25 estimated based on publicly available information) $[28,62,63]$.

The real-time EMT simulators that are available commercially include RSCAD ${ }^{\circledR}$, HYPERSIM, eMEGASIM, Typhoon, among others. They have the capability to simulate up to 9,000 three-phase nodes in 270 cores in real-time with 10-100 $\mu$ s time steps [64]. The number of nodes per core in real-time simulation is up to $30-40$ nodes/core [60,57]. The typical time step is on the order of 10-100 $\mu$ s. The number of states per unit simulated is on the order of tens of thousands (with a maximum of 17,000 estimated). The total number of states simulated is on the order of millions (with a maximum of 4.5 million estimated). There are capabilities to perform hybrid EMT-TS simulations using ePHASORSIM and eMEGASIM [60], RSCAD ${ }^{\circledR}$ [65], Open Distribution System Simulator (OpenDSS), and Typhoon [66], among others.

\subsection{TS SIMULATION TOOLS (OFFLINE/REAL-TIME)}

Several TS simulators currently exist, including PSS ${ }^{\circledR} E$, Positive Sequence Load Flow (PSLF), EMTPRV, EUROSTAG®, CYME, NEPLAN, PowerWorld, DIgSILENT PowerFactory, Power System Analysis Toolbox, Transient Security Assessment Tool (TSAT), ETAP, and others that. These programs have the capability to simulate balanced regional/continental transmission networks with up to 150,000 buses, and these simulators can perform positive-sequence phasor-domain simulations. They have been typically used to perform contingency analysis, stability analysis, protection coordination analysis, among others. There are TS simulators that can perform three-phase phasor-domain simulations like PSS ${ }^{\circ}$ SINCAL, DIgSILENT PowerFactory, NEPLAN, CYME Distribution Analysis (CYMDIST), OpenDSS, GridLAB-D ${ }^{\mathrm{TM}}$, and others that can simulate several thousands of nodes. The typical duration of simulation in TS simulators is up to $60 \mathrm{~s}$ with a time step of millisecond(s). The number of states 
simulated is on the order of millions (with a maximum of up to 3.5 million estimated) and the time taken to simulate ranges from 0.5 to $1 \mathrm{~h}[28]$.

The real-time TS simulators available in market include ePHASORSIM, RSCAD $\left.{ }^{\circledR}\right)$, among others. They have the capability to simulate up to 10,000 nodes per core in real-time with a typical time step of 1-20 $\mathrm{ms}$ [60]. The typical time step is on the order of 1-20 ms. The number of states per unit is on the order of tens of thousands (with a maximum of 21,000 estimated). The total number of states simulated is on the order of hundreds of thousands (with a maximum of 220,000 estimated) [60].

The characterization of the existing dynamic simulators and real-time dynamic simulators are provided in Tables 4 and 5 below. 
Table ES-4. Characterization of the existing dynamic simulators.

\begin{tabular}{|c|c|c|c|c|c|c|}
\hline $\begin{array}{c}\text { Type of } \\
\text { Simulator } \\
\text { (Time-Steps) }\end{array}$ & $\begin{array}{l}\text { Duration of } \\
\text { Simulation }\end{array}$ & $\begin{array}{l}\text { Modeling } \\
\text { Domain } \\
\text { (Simulator } \\
\text { Examples) }\end{array}$ & $\begin{array}{c}\text { Grid } \\
\text { Simulated }\end{array}$ & $\begin{array}{l}\text { Size of Study } \\
\text { System }\end{array}$ & $\begin{array}{l}\text { Typical Time } \\
\text { Taken to } \\
\text { Simulate }\end{array}$ & $\begin{array}{c}\text { Type of Studies } \\
\text { Performed }\end{array}$ \\
\hline \multirow[t]{2}{*}{$\begin{array}{l}\text { TS simulator } \\
(\sim \mathrm{ms})\end{array}$} & \multirow[t]{2}{*}{$\sim 60 \mathrm{~s}$} & $\begin{array}{l}\text { Positive } \\
\text { sequence } \\
\text { phasor-domain } \\
\text { (PSS E, PSLF, } \\
\text { ETAP, EMTP- } \\
\text { RV, } \\
\text { PowerFactory, } \\
\text { TSAT }\end{array}$ & $\begin{array}{l}\text { Transmission; } \\
\text { Balanced }\end{array}$ & $\begin{array}{l}\text { Regional/ } \\
\text { Continental (Up } \\
\text { to } 150,000 \\
\text { buses) }\end{array}$ & \multirow[t]{2}{*}{$\begin{array}{l}0.5-1 \mathrm{~h} \text { (up to } \\
3.5 \text { million } \\
\text { states estimated } \\
\text { to be simulated) }\end{array}$} & \multirow[t]{2}{*}{$\begin{array}{l}\text { Contingency } \\
\text { analysis, } \\
\text { stability } \\
\text { analysis, } \\
\text { protection } \\
\text { analysis }\end{array}$} \\
\hline & & $\begin{array}{l}\text { Three-phase } \\
\text { phasor-domain } \\
\text { (PSS } ® S I N C A L \\
\text {, PowerFactory, } \\
\text { GridLAB-D }{ }^{\mathrm{TM}} \text { ) }\end{array}$ & $\begin{array}{l}\text { Distribution; } \\
\text { Unbalanced }\end{array}$ & $\begin{array}{l}\text { Local (Several } \\
1,000 \text { s of } \\
\text { nodes) }\end{array}$ & & \\
\hline $\begin{array}{l}\text { EMT simulator } \\
(\sim 1-50 \mu \mathrm{s})\end{array}$ & $\sim 30 \mathrm{~s}$ & $\begin{array}{l}\text { Three-phase } \\
\text { time domain } \\
\text { (PSCAD, } \\
\text { EMTP-RV, } \\
\text { SPS, } \\
\text { PSS } ® S I N C A L, \\
\text { DIgSILENT } \\
\text { PowerFactory, } \\
\text { ETAP, ATP) }\end{array}$ & $\begin{array}{l}\text { Small } \\
\text { transmission, } \\
\text { distribution, } \\
\text { residential, } \\
\text { microgrids; } \\
\text { Balanced, } \\
\text { Unbalanced; }\end{array}$ & $\begin{array}{l}\text { Small number } \\
\text { of nodes } \\
\text { (studied up to } \\
1,000 \text { buses) }\end{array}$ & $\begin{array}{l}2.25-5 \text { h (up to } \\
7 \text { million states } \\
\text { estimated to be } \\
\text { simulated) }\end{array}$ & $\begin{array}{l}\text { Power } \\
\text { electronics } \\
\text { hardware } \\
\text { studies, } \\
\text { insulation } \\
\text { studies, } \\
\text { protection/ } \\
\text { stability studies }\end{array}$ \\
\hline $\begin{array}{l}\text { Component } \\
\text { simulator } \\
(\sim \mathrm{ns}-\mu \mathrm{s})\end{array}$ & $\sim 100 \mathrm{~s} \mathrm{~ms}-2 \mathrm{~s}$ & $\begin{array}{l}\text { Three-phase } \\
\text { time domain } \\
\text { (PLECS, PSim, } \\
\text { LT Spice, SPS, } \\
\text { PSCAD) }\end{array}$ & $\begin{array}{l}\text { Components } \\
\text { (like power } \\
\text { electronics and } \\
\text { semiconductor } \\
\text { devices) }\end{array}$ & $\begin{array}{l}\text { A few nodes } \\
\text { with power } \\
\text { electronics } \\
\text { system(s) }\end{array}$ & $\begin{array}{l}1 \mathrm{~min} \text { to } 10 \mathrm{~h} \\
\text { (up to } 50,000 \\
\text { states estimated } \\
\text { to be simulated) }\end{array}$ & $\begin{array}{l}\text { Power } \\
\text { electronics } \\
\text { hardware } \\
\text { studies }\end{array}$ \\
\hline TS simulator & $\begin{array}{l}\text { Positive- } \\
\text { sequence } \\
\text { phasor-domain } \\
\text { (ePHASORSI } \\
\text { M, RSCAD®) }\end{array}$ & $\begin{array}{l}\text { Transmission, } \\
\text { distribution; } \\
\text { Balanced, } \\
\text { unbalanced. }\end{array}$ & $\begin{array}{l}10,000 \\
\text { nodes/core } \\
\text { (max: } 30,000 \\
\text { nodes) }\end{array}$ & $\begin{array}{l}\text { Typical: } 1-20 \\
\text { ms }\end{array}$ & $\begin{array}{l}\text { Per Unit: } \\
\text { 10,000s/unit } \\
\text { (maximum: } \\
21,000 \\
\text { estimated), } \\
\text { Total: } \\
100,000 \mathrm{~s} \\
\text { (maximum: } \\
220,000 \\
\text { estimated) }\end{array}$ & $\begin{array}{l}\text { T\&D } \\
\text { interactions, } \\
\text { system of } \\
\text { power } \\
\text { converters, } \\
\text { protection } \\
\text { coordination, } \\
\text { cyber-secure } \\
\text { (physical) } \\
\text { systems }\end{array}$ \\
\hline
\end{tabular}


Table ES-5. Characterization of the existing real-time dynamic simulators.

\begin{tabular}{|c|c|c|c|c|c|c|}
\hline $\begin{array}{l}\text { Type of } \\
\text { Simulator }\end{array}$ & $\begin{array}{l}\text { Modeling } \\
\text { Domain } \\
\text { (Simulator } \\
\text { Examples) }\end{array}$ & $\begin{array}{c}\text { Grids } \\
\text { Simulated }\end{array}$ & $\begin{array}{l}\text { Size of Study } \\
\text { System }\end{array}$ & Time-steps & $\begin{array}{c}\text { States } \\
\text { Simulated }\end{array}$ & $\begin{array}{l}\text { Type of Studies } \\
\text { Performed }\end{array}$ \\
\hline EMT simulator & $\begin{array}{l}\text { Three-phase } \\
\text { time domain } \\
\text { (eMEGASIM, } \\
\text { HYPERSIM, } \\
\text { RSCAD®, } \\
\text { Typhoon) }\end{array}$ & $\begin{array}{l}\text { Transmission, } \\
\text { distribution, } \\
\text { microgrids; } \\
\text { Balanced, } \\
\text { unbalanced. }\end{array}$ & $\begin{array}{l}30-40 \text { three- } \\
\text { phase } \\
\text { buses/core } \\
\text { (max: } 9,000 \\
\text { three-phase } \\
\text { nodes/270 cores } \\
\text { tested) }\end{array}$ & $\begin{array}{l}\text { Typical: } 10-100 \\
\mu \mathrm{s}\end{array}$ & $\begin{array}{l}\text { Per Unit: } \\
\text { 10,000s/unit } \\
\text { (maximum: } \\
17,000 \\
\text { estimated) } \\
\text { Total: } \\
1,000,000 \mathrm{~s} \\
\text { (maximum: } \\
4,500,000 \\
\text { estimated) }\end{array}$ & $\begin{array}{l}\text { Passives, } \\
\text { control system, } \\
\text { cyber-secure } \\
\text { (physical) } \\
\text { systems for } \\
\text { components, } \\
\text { power } \\
\text { converter, } \\
\text { system of power } \\
\text { converters }\end{array}$ \\
\hline $\begin{array}{l}\text { Component } \\
\text { simulator }\end{array}$ & $\begin{array}{l}\text { Three-phase } \\
\text { time domain } \\
\text { (eFPGASim, } \\
\text { RSCAD }{ }^{\circledR} \text {, } \\
\text { Typhoon) }\end{array}$ & $\begin{array}{l}\text { Components } \\
\text { (Power } \\
\text { electronics } \\
\text { hardware) }\end{array}$ & $\begin{array}{l}128 \text { switches/ } \\
\text { FPGA } \\
\text { (max: } 6,000 \\
\text { SMs in MMCs) }\end{array}$ & Typical: 100s ns & $\begin{array}{l}\text { Per Unit: 100- } \\
\text { 1,000s/unit } \\
\text { (maximum: } \\
18,000 \\
\text { estimated) } \\
\text { Total: } 10,000 \text { s } \\
\text { (maximum: } \\
25,000 \\
\text { estimated) }\end{array}$ & $\begin{array}{l}\text { Modular power } \\
\text { electronics, } \\
\text { control system, } \\
\text { power converter }\end{array}$ \\
\hline
\end{tabular}

\subsection{POWER FLOW SIMULATION TOOLS (OFFLINE/REAL-TIME)}

Some of the examples of positive-sequence balanced power flow simulators include PSS®E, PSLF, EMTP-RV, EUROSTAG®, CYME, NEPLAN, PowerWorld, DIgSILENT PowerFactory, Power System Analysis Toolbox, Powerflow \& Short circuit Assessment Tool (PSAT), ETAP, Pandapower, MATACDC, and others that have the capability to simulate balanced regional/continental transmission networks with up to 150,000 buses in the transmission system. They have been used to perform full network analysis and contingency analysis that relates to identification of thermal and voltage limits, among others. There are three-phase power flow simulators like PSS ${ }^{\circledR} S I N C A L$, EMTP-RV, DIgSILENT PowerFactory, NEPLAN, CYMDIST, OpenDSS, GridLAB-D ${ }^{\mathrm{TM}}$, and others that can simulate up to 8,500 nodes in the distribution system. These simulations are typically at a specific snapshot in time domain. The number of states simulated is on the order of thousands (with a maximum of 160,000 estimated), and the EI grid described in [28] takes seconds to simulate.

\subsection{QSTS SIMULATION TOOLS (OFFLINE/REAL-TIME)}

The QSTS simulation tools, such as DIgSILENT PowerFactory, ETAP, among others, provide the capability to perform network analysis with renewables variability in transmission systems. These tools are based on positive-sequence phasor-domain analysis. They have been used to evaluate regional grids with up to 3,300 buses [42]. The typical time step can range from 1 to $300 \mathrm{~s}$, and the duration of simulation can be days to years. There are three-phase QSTS simulation tools like DIgSILENT PowerFactory, OpenDSS, GridLAB-D ${ }^{\mathrm{TM}}$, among others, that can simulate up to 8,500 distribution nodes [67]. These QSTS simulations can be run in faster-than-real-time depending on the size and simulation time steps. 
Real-time QSTS simulation is a new development. For example, there is ongoing research on GridLAB$\mathrm{D}^{\mathrm{TM}}$ that enables real-time simulations to analyze distribution grids with solar penetration and to evaluate demand response. This capability can study up to 8,500 nodes with a time step ranging between 1 and 60 s. It has been evaluated to perform cosimulations with PHIL capability [67].

The characterization of the existing steady-state simulators and real-time simulators are provided in Tables 6 and 7 below.

Table ES-6. Characterization of the existing steady-state simulators.

\begin{tabular}{|c|c|c|c|c|c|c|}
\hline $\begin{array}{c}\text { Type of } \\
\text { Simulator } \\
\text { (Time-Steps) }\end{array}$ & $\begin{array}{l}\text { Duration of } \\
\text { Simulation }\end{array}$ & $\begin{array}{l}\text { Modeling } \\
\text { Domain } \\
\text { (Simulator } \\
\text { Examples) }\end{array}$ & $\begin{array}{c}\text { Grid } \\
\text { Simulated }\end{array}$ & $\begin{array}{l}\text { Size of Study } \\
\text { System }\end{array}$ & $\begin{array}{l}\text { Typical Time } \\
\text { Taken to } \\
\text { Simulate }\end{array}$ & $\begin{array}{l}\text { Type of Studies } \\
\text { Performed }\end{array}$ \\
\hline \multirow[t]{2}{*}{$\begin{array}{l}\text { Power flow } \\
\text { studies } \\
(\sim 1-300 \mathrm{~s})\end{array}$} & \multirow[t]{2}{*}{ Snapshots } & $\begin{array}{l}\text { Positive } \\
\text { sequence } \\
\text { phasor-domain } \\
\text { (PSS®E, PSLF, } \\
\text { PowerFactory, } \\
\text { Pandapower, } \\
\text { MATACDC) }\end{array}$ & $\begin{array}{l}\text { Transmission; } \\
\text { Balanced }\end{array}$ & $\begin{array}{l}\text { Regional/ } \\
\text { Continental (Up } \\
\text { to } 150,000 \\
\text { buses) }\end{array}$ & \multirow[t]{2}{*}{$\begin{array}{l}\text { On the order of } \\
\text { seconds (up to } \\
160,000 \text { states } \\
\text { estimated to be } \\
\text { simulated) }\end{array}$} & $\begin{array}{l}\text { Full network } \\
\text { analysis, } \\
\text { contingency } \\
\text { analysis } \\
\text { (thermal, } \\
\text { voltage) }\end{array}$ \\
\hline & & $\begin{array}{l}\text { Three-phase } \\
\text { phasor-domain } \\
\text { (PSS®SINCAL } \\
\text {, PowerFactory, } \\
\text { OpenDSS, } \\
\text { GridLAB-D }\end{array}$ & $\begin{array}{l}\text { Distribution; } \\
\text { Unbalanced }\end{array}$ & $\begin{array}{l}\text { Local (Up to } \\
8,500 \text { nodes) }\end{array}$ & & $\begin{array}{l}\text { Full network } \\
\text { analysis, } \\
\text { reconfiguration } \\
\text { analysis }\end{array}$ \\
\hline \multirow[t]{2}{*}{$\begin{array}{l}\text { QSTS } \\
(\sim 1-300 \mathrm{~s})\end{array}$} & \multirow[t]{2}{*}{$\sim$ days to years } & $\begin{array}{l}\text { Positive } \\
\text { sequence } \\
\text { phasor-domain } \\
\text { (ETAP, } \\
\text { PowerFactory) }\end{array}$ & $\begin{array}{l}\text { Transmission; } \\
\text { Balanced }\end{array}$ & $\begin{array}{l}\text { Regional (Up to } \\
3,300 \text { buses) }\end{array}$ & \multirow[t]{2}{*}{$\begin{array}{l}\text { Faster-than- } \\
\text { real-time based } \\
\text { on size of } \\
\text { network and } \\
\text { simulation time } \\
\text { step }\end{array}$} & $\begin{array}{l}\text { Network } \\
\text { analysis (with } \\
\text { renewables } \\
\text { variability) }\end{array}$ \\
\hline & & $\begin{array}{l}\text { Three-phase } \\
\text { phasor-domain } \\
\text { (PowerFactory, } \\
\text { GridLAB-D } \\
\text { OpenDSS) }\end{array}$ & $\begin{array}{l}\text { Distribution; } \\
\text { Unbalanced }\end{array}$ & $\begin{array}{l}\text { Local (Up to } \\
8,500 \text { nodes) }\end{array}$ & & $\begin{array}{l}\text { Demand } \\
\text { response, } \\
\text { distribution } \\
\text { analysis with } \\
\text { solar }\end{array}$ \\
\hline
\end{tabular}

Table ES-7. Characterization of the existing steady-state simulators.

\begin{tabular}{|c|c|c|c|c|c|}
\hline Type of Simulator & $\begin{array}{l}\text { Modeling Domain } \\
\text { (Simulator } \\
\text { Examples) }\end{array}$ & Grids Simulated & $\begin{array}{l}\text { Size of Study } \\
\text { System }\end{array}$ & Time-steps & $\begin{array}{l}\text { Type of Studies } \\
\text { Performed }\end{array}$ \\
\hline QSTS studies & $\begin{array}{l}\text { Three-phase } \\
\text { unbalanced power } \\
\text { flows } \\
\text { (GridLAB-D }\end{array}$ & $\begin{array}{l}\text { Unbalanced; } \\
\text { Distribution }\end{array}$ & 8,500 nodes & Time step $1-60 \mathrm{~s}$ & $\begin{array}{l}\text { Distribution } \\
\text { analysis with solar, } \\
\text { demand response }\end{array}$ \\
\hline
\end{tabular}




\subsection{HARDWARE-IN-THE-LOOP SIMULATIONS}

Physical parts of a system are evaluated in HIL simulations, which enable testing and evaluation of the physical parts. The physical parts can be control systems, power electronics building blocks, power electronics systems, relays and breakers, among others. The following table (Table ES-8) illustrates some of the HIL simulators being used.

Table ES-8. Overview of HIL simulators.

\begin{tabular}{|c|c|c|c|c|}
\hline Location & $\begin{array}{c}\text { Power Amplifier } \\
\text { Ratings }\end{array}$ & $\begin{array}{l}\text { Test Results from } \\
\text { Publications }\end{array}$ & $\begin{array}{l}\text { Frequency } \\
\text { Rating }\end{array}$ & Operating modes \\
\hline Clemson University & $\begin{array}{l}15 \mathrm{MW}, 24 \mathrm{kV} \text { grid } \\
\text { simulator }(\sim \mathrm{ms} \text { speed })\end{array}$ & $4.16 \mathrm{kV}, 2.2 \mathrm{MW}$ & $45-65 \mathrm{~Hz}$ & $\mathrm{AC}$ \\
\hline \multirow{2}{*}{$\begin{array}{l}\text { Center for Advanced } \\
\text { Power Systems - } \\
\text { Florida State } \\
\text { University }\end{array}$} & $\begin{array}{l}5 \mathrm{MW}, 24 \mathrm{kV}(\sim \mathrm{ms} \\
\text { speed })\end{array}$ & & $\mathrm{DC}$ & $\mathrm{DC}$ \\
\hline & $\begin{array}{l}5 \mathrm{MVA}, 4.16 \mathrm{kV}(\sim \mathrm{ms} \\
\text { speed })\end{array}$ & $500 \mathrm{kVA}, 4.16 \mathrm{kV}$ & $45-65 \mathrm{~Hz}$ & $\mathrm{AC}$ \\
\hline $\begin{array}{l}\text { Idaho National } \\
\text { Laboratory }\end{array}$ & $\begin{array}{l}60 \mathrm{kVA}, 520 \mathrm{~V} \text { grid } \\
\text { simulator }(\sim \mathrm{ms} \text { speed })\end{array}$ & $\mathrm{N} / \mathrm{A}$ & $30-100 \mathrm{~Hz}$ & 4 quadrants \\
\hline \multirow[t]{2}{*}{$\begin{array}{l}\text { National Renewable } \\
\text { Energy Laboratory }\end{array}$} & $\begin{array}{l}1 \mathrm{MVA}, 520 \mathrm{~V} \text { grid } \\
\text { simulator } \\
\text { (with } 90 \mathrm{kVA} \times 12 \text { grid } \\
\text { simulators, ms speed) }\end{array}$ & $80 \mathrm{kVA}, 480 \mathrm{~V}$ & $16-820 \mathrm{~Hz}$ & $\begin{array}{l}\mathrm{AC}(90 \mathrm{kVA}), \mathrm{DC} \\
(60 \mathrm{KW}) \text { per unit }\end{array}$ \\
\hline & $\begin{array}{l}7 \mathrm{MVA}, 13.2 \mathrm{kV} \text { grid } \\
\text { simulator }\end{array}$ & $7 \mathrm{MVA}, 13.2 \mathrm{kV}$ & $45-60 \mathrm{~Hz}$ & $\mathrm{AC}$ \\
\hline \multirow[t]{3}{*}{$\begin{array}{l}\text { Oak Ridge National } \\
\text { Laboratory }\end{array}$} & $\begin{array}{l}\text { Modules }(2 \mathrm{kV}, 20 \mathrm{~A}) \\
\text { in large power } \\
\text { electronics system } \\
\text { evaluator (PE-HIL part } \\
\text { of FIRE platform) }\end{array}$ & $2 \mathrm{kV}, 20 \mathrm{~A}$ & Up to $120 \mathrm{~Hz}$ & $\begin{array}{l}\mathrm{AC}+\mathrm{DC} \text { with } \\
\text { square-wave } \\
\text { voltages from } \\
\text { modules }\end{array}$ \\
\hline & $\begin{array}{l}360 \mathrm{kVA}, 480 \mathrm{~V} \text { grid } \\
\text { simulator }(\sim \mathrm{ms} \text { speed })\end{array}$ & $\mathrm{N} / \mathrm{A}$ & $16-820 \mathrm{~Hz}$ & $\begin{array}{l}\mathrm{AC}(90 \mathrm{kVA}), \mathrm{DC} \\
(60 \mathrm{KW}) \text { per unit }\end{array}$ \\
\hline & $\begin{array}{l}\text { Device evaluation and } \\
\text { characterization }(10 \mathrm{kV} \text {, } \\
15 \mathrm{~A}) \text { for } \\
\text { semiconductor devices } \\
\text { characterization }\end{array}$ & & Double pulse & \\
\hline $\begin{array}{l}\text { Sandia National } \\
\text { Laboratories }\end{array}$ & $\begin{array}{l}180 \mathrm{kVA}, 520 \mathrm{~V} \text { grid } \\
\text { simulator }(\sim \mathrm{ms} \text { speed })\end{array}$ & N/A & $16-820 \mathrm{~Hz}$ & $\begin{array}{l}\mathrm{AC}(90 \mathrm{kVA}), \mathrm{DC} \\
(60 \mathrm{KW}) \text { per unit }\end{array}$ \\
\hline
\end{tabular}

\section{SCENARIOS, EVENTS DESCRIPTION, FUTURE GRID REQUIREMENTS, AND STANDARDS SUMMARY}

The scenarios of future grids and evolution of the component models in the grid identify the characteristics of future simulators and real-time simulators. The scenarios considered in this study are defined in Section 3.1. The evolution of the component models is based on historical evolution of models (explained in Section 3.2) and the complexity of the components expected in the future scenarios. The complexity of the component models is briefly summarized in Sections 3.3 and 3.4 for dynamic and steady-state simulators, respectively. Based on the evolution of the components and defined scenarios, the number of states that need to be simulated is estimated for future scenarios. The method is summarized in Figure ES-4. 


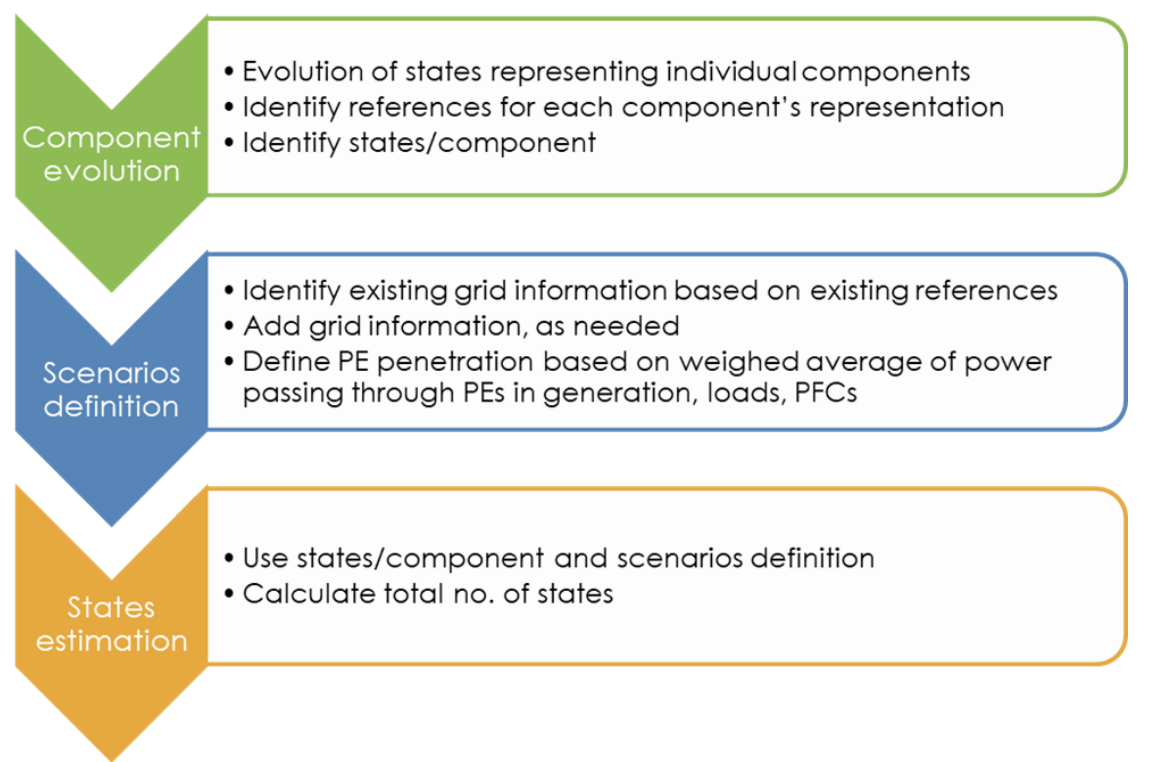

Figure ES-4. State estimation method for studying future scenarios of grid.

\subsection{SCENARIOS AND EVENT DESCRIPTION}

There are three scenarios being considered in this report. They include: (i) up to $20 \%$ penetration of power electronics (the traditional power system), (ii) 20-50\% penetration of power electronics (the intermediate scenario), and (iii) $50-100 \%$ penetration of power electronics (the future scenario). The term penetration of power electronics is defined in the section above. The characteristics of each scenario are summarized in Table ES-9.

Some of the challenges anticipated with higher penetration of power electronics include control interactions, subsynchronous interactions, increased sensitivity of power electronics to external disturbance that may affect the stability of the grid, low SCR, voltage variability, reduced inertia, among others. Some of these challenges have been highlighted by the NERC studies [18, 19, 20], MISO study [51], ERCOT study [25], and AEMO study [26]. As the penetration of power electronics increases, other challenges may arise. 
Table ES-9. Summary of characteristics of future scenarios.

\begin{tabular}{|c|c|c|c|}
\hline Characteristics & Traditional Power System & $\begin{array}{l}\text { Intermediate Scenario: } \\
\text { Power Electronics and } \\
\text { Traditional Components }\end{array}$ & $\begin{array}{c}\text { Long-Term Scenario: } \\
\text { High-Penetration Power } \\
\text { Electronics }\end{array}$ \\
\hline \multirow[t]{5}{*}{$\begin{array}{l}\text { Electrical } \\
\text { Components }\end{array}$} & $\begin{array}{l}\text { Generators: Synchronous } \\
\text { generators, low penetration of } \\
\text { wind/PV plants/ DERs }\end{array}$ & $\begin{array}{l}\text { Generators: Synchronous } \\
\text { generators, variable-speed } \\
\text { drives in synchronous } \\
\text { generators, medium } \\
\text { penetration of } \\
\text { wind/PV/Energy Storage } \\
\text { (ES)/DERs }\end{array}$ & $\begin{array}{l}\text { Generators: power } \\
\text { electronics sourced } \\
\text { generations (wind, PV, } \\
\text { ES, variable-speed drives } \\
\text { connecting to } \\
\text { conventional sources like } \\
\text { steam turbines, } \\
\text { hydroelectric turbines, } \\
\text { etc.), DERs }\end{array}$ \\
\hline & $\begin{array}{l}\text { Transformers: Tap-changing } \\
\text { transformers, uncontrolled } 60 \\
\text { Hz transformers }\end{array}$ & $\begin{array}{l}\text { Transformers: Uncontrolled } \\
60 \mathrm{~Hz} \text { transformers, } \\
\text { distribution SSPS } 1.0[68]\end{array}$ & $\begin{array}{l}\text { Transformers: SSPS } 3.0 \\
\text { with power electronics } \\
\text { controlled transformers } \\
{[68]}\end{array}$ \\
\hline & $\begin{array}{l}\text { Power Flow Controllers and } \\
\text { Reactive Power Compensators: } \\
\text { Few HVdc lines, more static } \\
\text { VAR compensators and } \\
\text { uncontrolled reactor banks than } \\
\text { stationary compensators } \\
\text { (STATCOMs) or static } \\
\text { synchronous series } \\
\text { compensators (SSSC) }\end{array}$ & $\begin{array}{l}\text { Power Flow Controllers and } \\
\text { Reactive Power } \\
\text { Compensators: More HVdc, } \\
\text { more power electronics-based } \\
\text { FACTS/ Distribution-FACTS } \\
\text { (D-FACTS) like smart wires, } \\
\text { STATCOMs, and SSSCs, } \\
\text { and lesser mechanically } \\
\text { switched, uncontrolled } \\
\text { reactor banks }\end{array}$ & $\begin{array}{l}\text { Power Flow Controllers } \\
\text { and Reactive Power } \\
\text { Compensators: HVdc, } \\
\text { MVdc, power electronics- } \\
\text { based FACTS, power } \\
\text { electronics-based D- } \\
\text { FACTS, fault limiters }\end{array}$ \\
\hline & $\begin{array}{l}\text { Protection: Mechanical } \\
\text { breakers }\end{array}$ & $\begin{array}{l}\text { Protection: Mechanical } \\
\text { breakers, hybrid breakers }\end{array}$ & $\begin{array}{l}\text { Protection: Solid-state } \\
\text { breakers, hybrid breakers }\end{array}$ \\
\hline & $\begin{array}{l}\text { Loads: Machine-based loads } \\
\text { (induction machines), low } \\
\text { penetration of } \\
\text { DERs/ES/electric vehicle (EV) } \\
\text { chargers, incandescent lighting }\end{array}$ & $\begin{array}{l}\text { Loads: Machine-based loads } \\
\text { (induction machines), } \\
\text { medium penetration of } \\
\text { DERs/ES/variable-speed } \\
\text { drives, high penetration of } \\
\text { wired fast EV chargers, solid- } \\
\text { state lighting }\end{array}$ & $\begin{array}{l}\text { Loads: Variable-speed } \\
\text { drives, extreme fast EV } \\
\text { chargers (wired and } \\
\text { wireless) with power } \\
\text { electronics, DERs/ES, } \\
\text { solid-state lighting }\end{array}$ \\
\hline $\begin{array}{l}\text { Control and } \\
\text { Communication }\end{array}$ & $\begin{array}{l}\text { Transmission Communication: } \\
1 \text { G Ethernet for supervisory } \\
\text { control and data acquisition } \\
\text { (SCADA) from field sensors } \\
\text { (programmable logic } \\
\text { controllers - PLCs, remote } \\
\text { terminal units - RTUs, phasor } \\
\text { measurement units - PMUs) } \\
\text { Distribution Communication: } \\
\text { Limited communication } \\
\text { present with switches and RTU } \\
\text { data exchanges }\end{array}$ & $\begin{array}{l}\text { Transmission } \\
\text { Communication: } 100 \mathrm{G} \\
\text { Ethernet for SCADA } \\
\text { Distribution Communication: } \\
100 \text { G Ethernet for real-time } \\
\text { data exchange from DERs, } \\
\text { feeders (and greater sensor } \\
\text { deployment), smart loads }\end{array}$ & $\begin{array}{l}\text { Transmission } \\
\text { Communication: Very } \\
\text { high-speed } \\
\text { communication } \\
\text { Distribution } \\
\text { Communication: Very } \\
\text { high-speed } \\
\text { communication from } \\
\text { DERs, feeders, smart } \\
\text { loads, smart buildings }\end{array}$ \\
\hline
\end{tabular}


Table ES-9. Summary of characteristics of future scenarios (continued).

\begin{tabular}{|c|c|c|c|}
\hline Characteristics & Traditional Power System & $\begin{array}{l}\text { Intermediate Scenario: } \\
\text { Power Electronics and } \\
\text { Traditional Components }\end{array}$ & $\begin{array}{c}\text { Long-Term Scenario: } \\
\text { High-Penetration Power } \\
\text { Electronics }\end{array}$ \\
\hline & $\begin{array}{l}\text { Transmission Control: Central } \\
\text { energy management system } \\
\text { (EMS), human machine } \\
\text { interface (HMI), and } \\
\text { decentralized voltage/ } \\
\text { frequency control in } \\
\text { transmission systems } \\
\text { Distribution Control: Control } \\
\text { switches to change } \\
\text { configuration }\end{array}$ & $\begin{array}{l}\text { Transmission Control: } \\
\text { Automated EMS with } \\
\text { minimum human interaction } \\
\text { Distribution Control: DER } \\
\text { management system } \\
\text { (DERMS), advanced } \\
\text { distribution management } \\
\text { system (ADMS) } \\
\text { Microgrid Control: } \\
\text { Microgrid Central Controller } \\
\text { (MGCC) }\end{array}$ & $\begin{array}{l}\text { Control: Centralized- } \\
\text { Decentralized control in } \\
\text { nanogrids-microgrids- } \\
\text { distribution-transmission } \\
\text { systems }\end{array}$ \\
\hline & $\begin{array}{l}\text { Sensors: PLCs, RTUs, PMUs } \\
\text { in transmission systems. There } \\
\text { are few digital fault recorders } \\
\text { (DFRs). Limited sensors in } \\
\text { distribution systems. }\end{array}$ & $\begin{array}{l}\text { Sensors: PLCs, RTUs, PMUs } \\
\text { with increased bandwidth in } \\
\text { transmission systems. } \\
\text { Increased presence of } \\
\text { distribution PMUs, digital } \\
\text { fault recorders (DFRs), and } \\
\text { other high bandwidth sensors } \\
\text { in distribution/transmission. }\end{array}$ & $\begin{array}{l}\text { Sensors: High bandwidth } \\
\text { sensors in distribution/ } \\
\text { microgrids/transmission/ } \\
\text { nanogrids (buildings). }\end{array}$ \\
\hline Interconnections & Heavily interconnected system & $\begin{array}{l}\text { Interconnected with a } \\
\text { percentage of asynchronous } \\
\text { islanded systems (and } \\
\text { potentially can dynamically } \\
\text { island) }\end{array}$ & $\begin{array}{l}\text { Asynchronous, decoupled, } \\
\text { firewalled, fractal sections } \\
{[68]}\end{array}$ \\
\hline
\end{tabular}

\subsection{MODEL COMPLEXITY}

In recent history, an evolution and significant increase of modeling complexity have been observed in industry's modeling practice. The increase in complexity has been observed in renewable generation modeling and more significantly in the load models. Such evolution of industry-grade models is a motivation for our investigation of modeling gaps and illustrates the modeling process evolution in the power industry. Three aspects are briefly discussed:

1. Evolution of complexity in loads (Figure ES-5 [a]): When computer-based power system simulation emerged in 1960s-1980s, the static load models [69] were adopted. The complexity of the static load model increased from 1960s to 1980s. After the 1996 North America blackout, engineers realized that the static load models are inadequate for reproducing low-frequency power oscillations [70]. Therefore, a prototype dynamic induction motor model was developed and adopted in combination with static load model [71]. After the 2000s, Siemens Power Technologies International (PTI) adopted a more complex composite load model explicitly representing aggregations of large and small motors, nonlinear models of discharge lighting, transformer saturation effects, constant megavolt-ampere, shunt capacitors, and a series impedance and tap ratio to static load models in [69]. However, this model is unable to reproduce the fault-induced delayed voltage recovery (FIDVR) phenomenon caused by cascaded stalling of residential air conditioner motors. To represent FIDVR, WECC initiated a load modeling task force (LMTF) involving several utilities, national laboratories, and a General Electric (GE) PSLF vendor to co-develop a WECC composite load model (CMPLDW) that includes an aggregate air conditioner model as one component [72]. 
2. Adding dynamic models of DERs to load models (Figure ES-5 [b]): Recently, DERs became more prevalent in distribution feeders. This led to an aggregate DER model being explicitly added to the composite load model CMPLDW [73]. The new WECC composite load model (CMPLDWG) that includes DER_A controls has more than 160 parameters (CMPLDW + DER_A) and is the most sophisticated transmission-level load model implemented in various power system TS simulators.

3. Evolving modeling of renewable generation (Figure ES-6): In the early 2000s, development of the first generation of dynamic generic models for renewables started in WECC. In 2010, WECC started the development of the second generation of generic models [74]. In parallel, in 2010, the International Electrotechnical Commission (IEC) started a similar modeling effort. WECC started formally adopting the models in late 2014 and early 2015, and by this time the vast majority of the first generation of generic models had been replaced in the WECC official database. Adoption of these models in the EI has been slower. Since 2016, the WECC revisited the second generation of generic models and proposed modifications to further improve their applicability [75], [76]. The generic models currently have several shortcomings, especially for weak grids with high penetration of renewable generation, as discussed in [77]. To resolve these shortcomings, it is expected that modeling complexity for renewable generation will continue to evolve, likely into more detailed models.

Similar to the power grid's evolution, the models are expected to evolve as increasing levels of power electronics-based equipment are installed.

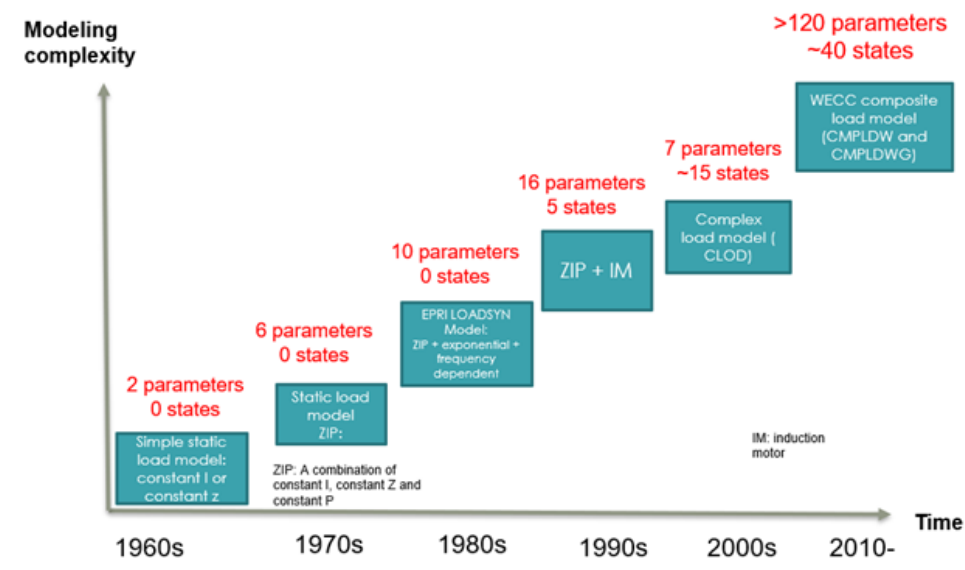

(a)

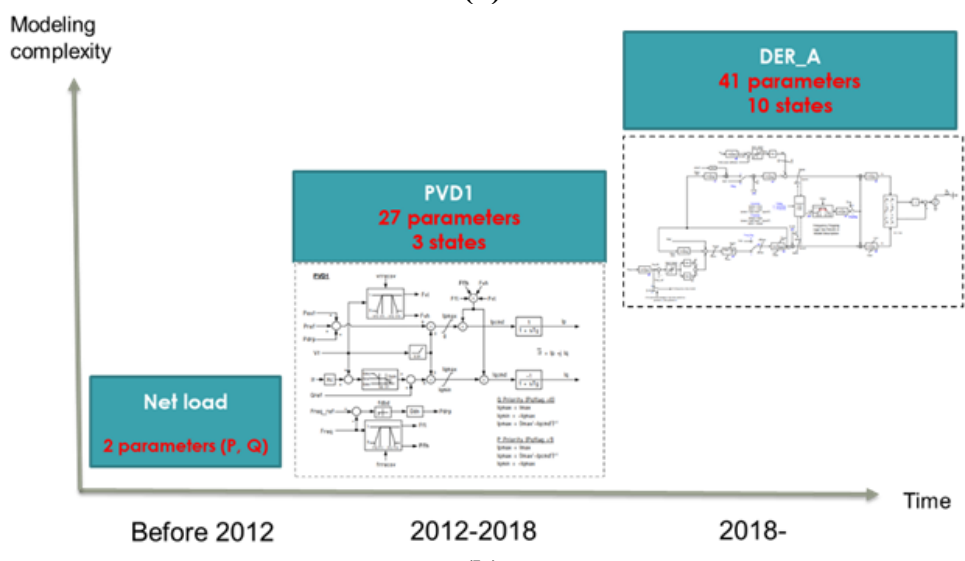

(b)

Figure ES-5. Evolution of Load and Distributed Generation Models. 


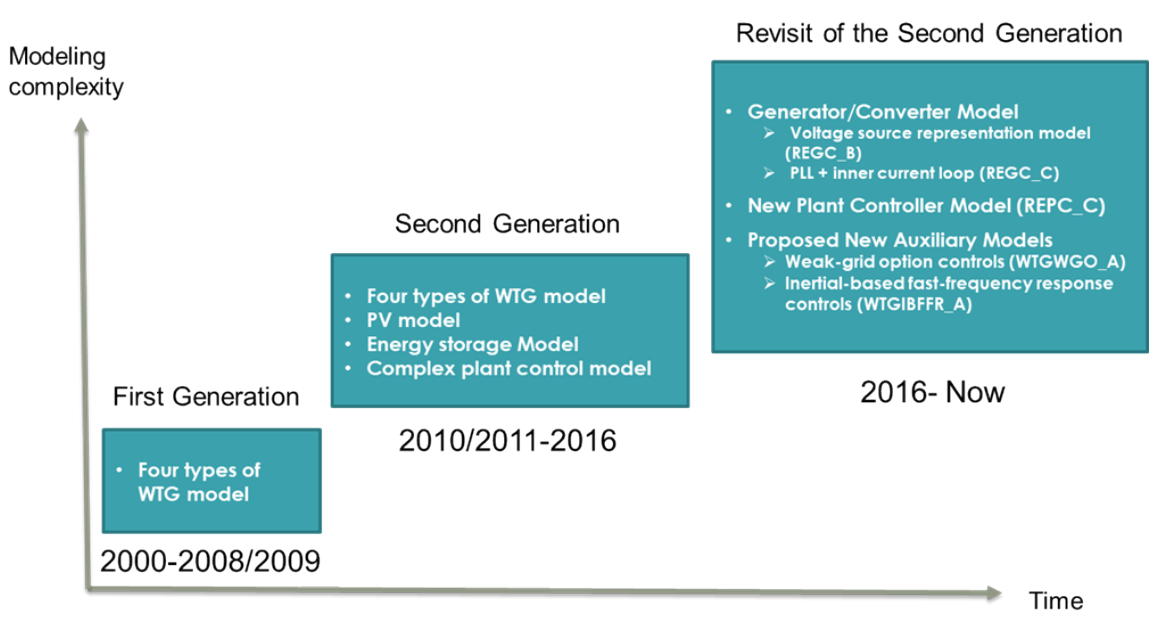

Figure ES-6. WECC generic renewable dynamic models evolution.

\subsection{DYNAMIC SIMULATION STUDY REQUIREMENTS}

Component Simulation Tools: The increased requirements in component simulators for future scenarios arise from the advances in semiconductor technology that has increasingly adopted the wideband gap semiconductor devices like silicon carbide $(\mathrm{SiC})$ and gallium nitride $(\mathrm{GaN})$. The $\mathrm{SiC}$ and $\mathrm{GaN}$ semiconductor devices can switch much faster than the traditional silicon ( $\mathrm{Si}$ ) semiconductor devices, thereby reducing the time step required in component simulations. Moreover, there is a trend toward highfrequency transformer utilization compared to the traditional $60 \mathrm{~Hz}$ bulky transformer in niche applications that may also be used in SSPS 1.0, 2.0, and 3.0. These trends require the utilization of smaller time steps than today's typical time step considered in component simulations. Moreover, the complexity of the power electronics' circuit architecture is expected to increase with increased penetration of power electronics through multilevel converters and dual-active bridge converters, among others. The complexity of the power electronics' models is expected to increase for higher fidelity of models to perform electrical, magnetic, and thermal simulations. These complexities will increase the number of states simulated in component simulations. The time taken to simulate will need to be reduced to enable enhanced utilization of the component simulation tools that can simulate high-fidelity models of complex power electronics. The changes desired in time steps, number of states to be simulated, and time taken to simulate will also enable faster-than-real-time component simulation that can be used in digital twins of components for predictive maintenance and diagnostics.

The real-time simulation tool to simulate components will require the corresponding changes in timesteps. It will also require increased number of states to be simulated per unit and total number of states simulated. While the former accounts for faster switching semiconductor devices and the complexity of power electronics' circuit architecture, the latter accounts for increased fidelity of models and complexity of power electronics' circuit architecture. The real-time simulation tool to simulate components will be used to evaluate modular power electronics, passives, control systems of components, cyber-security systems in components, single power electronics equipment, among others, in HIL configuration.

EMT Simulation Tools: Based on the challenges observed with local high-penetration of power electronics that have been studied in California and by ERCOT, NE-ISO, AEMO, and others, there is an increasing need for EMT simulation of larger systems to study contingencies, stability of systems, protection systems, power electronics hardware and control interactions, resilience, and fast real-time scheduling. The larger systems may include the local transmission systems with detailed distribution systems, regional transmission systems, among others in the intermediate scenario, and larger continental 
size transmission systems, regional transmission systems with detailed distribution systems, among others in the future scenario. Moreover, the fidelity of individual component model will also be increased to study high bandwidth responses and sensitivities to external disturbances observable in such systems. The increased fidelity also arises from complex power electronic circuits. The increased fidelity of the models will be observed in the models of power electronics, transformers, transmission lines, among others. The power electronics will be present in SSPS 1.0, utility-scale power electronics-based generations, DER power electronics, and loads like EV chargers in the intermediate scenario. The power electronics will be present in SSPS 3.0, SSPS 2.0, SSPS 1.0, power electronics-based generations, DER power electronics, and loads like EV chargers and variable-speed drives. Based on these trends, the number of states simulated in EMT simulations will increase tremendously. These are calculated based on the intermediate and long-term scenarios with the complexity introducing by improved fidelity of models incorporated. The time step of EMT simulations will also change with the high bandwidth components in the grid that include the high-frequency transformers, wideband gap device based faster power electronics, among others. The time taken to simulate needs to be decreased to the time taken by conventional TS simulations for improved utilization of the EMT tools. The changes desired in time steps, number of states to be simulated, and time taken to simulate will also enable faster-than-real-time EMT simulation of smaller regions that are not feasible today in operational tools like online dynamic security assessment (DSA) tools.

The real-time simulation tool to perform EMT simulations will require the corresponding changes in time steps. It will also require increased number of states per unit and total number of states. Although the former accounts for the need to simulate higher bandwidth components and possible control interactions between the components, the latter accounts for the need to simulate larger systems with higher fidelity models. The real-time EMT simulation will be used to evaluate the interaction of the control system in a single power electronics system with the grid, interaction of multiple control systems in multiple power electronics, stability and interactions of hierarchical control system (like EMS and the distribution management system - DMS) in transmission-distribution systems, protection coordination in transmission-distribution systems, cyber-security systems in transmission-distribution systems, among others.

Hybrid EMT-TS Simulation Tools: There will also be an increasing trend toward reducing the computational burden of performing very large-scale EMT simulations by using hybrid EMT-TS simulations. To study future scenarios, the number of boundary buses will need to be increased in such simulations in future scenarios that can be estimated based on one such scenario studied in [28]. These simulations can be used for contingency analysis, stability analysis, protection analysis, and resilience studies.

TS Simulation Tools: There will be continued need for TS simulations of future scenarios to perform contingency analysis, stability analysis, protection analysis, resilience studies, and fast real-time dispatch scheduling. The increased penetration of distributed generation will necessitate integrated transmissiondistribution system studies over large areas that could be an interconnection or several asynchronous interconnections that are connected through direct current (dc) links. These requirements will result in increased number of states that need to be simulated along with the reduction in time steps to account for reduced inertia from distributed generation. Moreover, the time taken to simulate can be reduced through advances in computing solutions. The changes desired in time steps, number of states to be simulated, and time taken to simulate will also enable faster-than-real-time TS simulation of larger systems and/or higher number of contingencies that are not feasible today in operational tools like online DSA tools.

The real-time simulation tool to perform TS simulations will require increased number of states per unit and total number of states. Although the former accounts for the reduced inertia introduced by increased distributed generation and the requirements to simulate distribution grids, the latter accounts for the need 
to simulate larger systems. The real-time TS simulation will be used to evaluate the stability and interactions of hierarchical control system (like the EMS and DMS) in transmission-distribution systems, protection coordination in transmission-distribution systems, cyber-security systems in transmissiondistribution systems, among other uses. In some cases, tools that perform hybrid EMT-TS simulations in real-time may be used.

The discussions in this section are summarized in Table ES-10.

Table ES-10. Summary of dynamic study requirements in future grids.

\begin{tabular}{|c|c|c|c|c|c|c|}
\hline Study-of-Interest & $\begin{array}{l}\text { Modeling } \\
\text { Domain }\end{array}$ & $\begin{array}{l}\text { Study } \\
\text { System } \\
\text { Size }\end{array}$ & Timescales & $\begin{array}{c}\text { Duration } \\
\text { of } \\
\text { Simulation }\end{array}$ & Cosimulation & $\begin{array}{c}\text { Model } \\
\text { Requirements }\end{array}$ \\
\hline $\begin{array}{l}\text { Contingency analysis } \\
\text { (e.g., N-1-1/N-1, } \\
\text { faults, response from } \\
\text { faults like FIDVR, } \\
\text { generator losses, } \\
\text { component losses, } \\
\text { large contingencies - } \\
\text { cascading events, etc.) }\end{array}$ & $\begin{array}{l}\text { Time } \\
\text { domain }\end{array}$ & $\begin{array}{l}\text { Can be } \\
\text { large area } \\
\sim 1,000,00 \\
\text { 0s nodes }\end{array}$ & EMT (TS) & $\begin{array}{l}\text { Seconds to } \\
1 \text { min }\end{array}$ & $\begin{array}{l}\text { EMT-TS is a } \\
\text { possibility }\end{array}$ & $\begin{array}{l}\text { TS models of } \\
\text { generators, three- } \\
\text { phase EMT model } \\
\text { of components } \\
\text { (including power } \\
\text { electronics-based } \\
\text { generations, } \\
\text { transformers, } \\
\text { sources), detailed } \\
\text { transmission line } \\
\text { models, protection } \\
\text { system models. }\end{array}$ \\
\hline $\begin{array}{l}\text { Stability analysis } \\
\text { (e.g., negative } \\
\text { impedances, control } \\
\text { interactions, } \\
\text { subsynchronous } \\
\text { resonances) }\end{array}$ & $\begin{array}{l}\text { Time } \\
\text { domain }\end{array}$ & $\begin{array}{l}\text { Can be } \\
\text { large area } \\
\sim 1,000,00 \\
\text { 0s nodes }\end{array}$ & EMT (TS) & $\begin{array}{l}\text { Seconds to } \\
1 \text { min }\end{array}$ & $\begin{array}{l}\text { EMT-TS, with } \\
\text { TS of } \\
\text { generators and } \\
\text { EMT of } \\
\text { systems/ } \\
\text { components }\end{array}$ & $\begin{array}{l}\text { TS models of } \\
\text { generators, three- } \\
\text { phase EMT model } \\
\text { of components } \\
\text { (including power } \\
\text { electronics-based } \\
\text { generations, } \\
\text { transformers, } \\
\text { sources), detailed } \\
\text { transmission line } \\
\text { models. }\end{array}$ \\
\hline
\end{tabular}


Table ES-10. Summary of dynamic study requirements in future grids (continued).

\begin{tabular}{|c|c|c|c|c|c|c|}
\hline $\begin{array}{l}\text { Study-of- } \\
\text { Interest }\end{array}$ & $\begin{array}{l}\text { Modeling } \\
\text { Domain }\end{array}$ & $\begin{array}{l}\text { Study System } \\
\text { Size }\end{array}$ & Timescales & $\begin{array}{l}\text { Duration of } \\
\text { Simulation }\end{array}$ & Cosimulation & $\begin{array}{c}\text { Model } \\
\text { Requirements }\end{array}$ \\
\hline $\begin{array}{l}\text { Protection } \\
\text { analysis } \\
\text { (ac-dc, dc only, } \\
\text { dynamic and } \\
\text { adaptive } \\
\text { strategies) }\end{array}$ & $\begin{array}{l}\text { Time domain } \\
\text { (Phasor- } \\
\text { domain) }\end{array}$ & $\begin{array}{l}\text { Can be small- } \\
\text { area or large- } \\
\text { area } \\
\sim 1,000,000 \mathrm{~s} \\
\text { nodes }\end{array}$ & EMT (TS, PF) & $\begin{array}{l}\text { Seconds to } \\
1 \mathrm{~min}\end{array}$ & $\begin{array}{l}\text { EMT-TS } \\
\text { PF snapshots } \\
\text { (short circuit } \\
\text { analysis) }\end{array}$ & $\begin{array}{l}\text { Full three-phase } \\
\text { with detailed } \\
\text { power } \\
\text { electronics } \\
\text { models; } \\
\text { average-value } \\
\text { models; } \\
\text { subtransient } \\
\text { impedances in } \\
\text { short circuit } \\
\text { analysis (PF). }\end{array}$ \\
\hline $\begin{array}{l}\text { Power } \\
\text { electronic } \\
\text { hardware } \\
\text { studies } \\
\text { (e.g., HVdc, } \\
\text { SSTs, MVdc) }\end{array}$ & Time domain & $\begin{array}{l}\text { Can be in a } \\
\text { smaller area } \\
\sim 100,000 \text { nodes }\end{array}$ & EMT & $\begin{array}{l}\text { Milliseconds to } \\
\text { seconds }\end{array}$ & $\begin{array}{l}\text { EMT- } \\
\text { Component } \\
\text { models }\end{array}$ & $\begin{array}{l}\text { Three-phase } \\
\text { EMT models } \\
\text { with detailed } \\
\text { power } \\
\text { electronics } \\
\text { models, } \\
\text { subcomponent } \\
\text { detailed models } \\
\text { (e.g., } \\
\text { semiconductors, } \\
\text { inductors, etc.). }\end{array}$ \\
\hline $\begin{array}{l}\text { Resilience } \\
\text { studies } \\
\text { (e.g., black } \\
\text { start, degrade } \\
\text { gracefully, } \\
\text { islanding, etc.) }\end{array}$ & Time domain & $\begin{array}{l}\text { Can be in a } \\
\text { small or large } \\
\text { area } \\
\sim 1,000,000 \text { s }\end{array}$ & $\begin{array}{l}\text { EMT (TS, } \\
\text { QSTS) }\end{array}$ & $\begin{array}{l}\text { Seconds to } \\
\text { hours }\end{array}$ & $\begin{array}{l}\text { EMT-TS is a } \\
\text { possibility } \\
\text { (based on } \\
\text { duration-area of } \\
\text { study) } \\
\text { QSTS may be } \\
\text { needed for } \\
\text { longer durations } \\
\text { with EMT-TS } \\
\text { for shorter } \\
\text { durations }\end{array}$ & $\begin{array}{l}\text { Three-phase } \\
\text { EMT models } \\
\text { including } \\
\text { average-value } \\
\text { models/ detailed } \\
\text { power } \\
\text { electronics } \\
\text { models; models } \\
\text { of inductors, } \\
\text { transformer } \\
\text { models, etc. }\end{array}$ \\
\hline $\begin{array}{l}\text { Fast real-time } \\
\text { scheduling } \\
\text { (e.g., seconds } \\
\text { dispatches in } \\
\text { regions) }\end{array}$ & Phasor-domain & $\begin{array}{l}\text { Can be large } \\
\text { area } \\
\sim 1,000,000 \mathrm{~s}\end{array}$ & TS (PF, QSTS) & $\begin{array}{l}\text { Seconds to } \\
\text { hours }\end{array}$ & $\begin{array}{l}\text { TS with } \\
\text { interactions to } \\
\text { quasi-steady } \\
\text { state analysis }\end{array}$ & $\begin{array}{l}\text { Full three-phase } \\
\text { with new } \\
\text { models to } \\
\text { represent the } \\
\text { faster } \\
\text { scheduling. }\end{array}$ \\
\hline
\end{tabular}

\subsection{POWER FLOW/QSTS SIMULATION STUDY REQUIREMENTS}

Power flow: NERC [PNNL 1.2.3-6] currently requires transmission operators and reliability coordinators to perform contingency analysis every $30 \mathrm{~min}$ using real-time information. The contingency analysis is currently based on power flow solutions. This means that transmission operators and reliability coordination need to solve algorithms and analyze results of many contingencies within a short time. In addition, T\&D simulations, with significantly higher number of buses, are expected to be needed to study the future grid with increased penetration of power electronics devices. Therefore, high performance 
computation of power flow algorithms with increased complexities are desired. The study requirements are summarized in Table ES-11.

QSTS: Currently QSTS simulations have been largely focused on distribution. In the future grid, QSTS simulation will need to be run considering both transmission and distribution. The networks models increase in complexity and number of buses. Complexity could also increase from the need for iteration between models to accurately capture T\&D interactions as well as ac-dc system interactions. The time steps required could become shorter, in the order of seconds, as more variable generation is considered. Finally, the time to simulate could be required to be significantly reduced to allow for analysis in reasonable time. The QSTS requirements in future grids are summarized in Table ES-12.

Table ES-11. Summary of power flow study requirements in future grids.

\begin{tabular}{|c|c|c|c|c|c|c|}
\hline $\begin{array}{l}\text { Study-of- } \\
\text { Interest }\end{array}$ & $\begin{array}{l}\text { Modeling } \\
\text { Domain }\end{array}$ & $\begin{array}{l}\text { Study } \\
\text { System } \\
\text { Size }\end{array}$ & Timescales & $\begin{array}{l}\text { Duration of } \\
\text { Simulation }\end{array}$ & $\begin{array}{c}\text { Cosimulati } \\
\text { on }\end{array}$ & Model Requirements \\
\hline $\begin{array}{l}\text { Evaluation and } \\
\text { design of slow } \\
\text { controls } \\
\text { (Transmission/su } \\
\text { btransmission } \\
\text { and/or } \\
\text { distribution } \\
\text { analysis with } \\
\text { high penetration } \\
\text { of DER- } \\
\text { combined ac and } \\
\text { dc analysis) }\end{array}$ & $\begin{array}{l}\text { Transmission: } \\
\text { Phasor - dc } \\
\text { systems } \\
\text { Distribution: } \\
\text { Three-phase } \\
\text { unbalanced - dc } \\
\text { systems }\end{array}$ & $\begin{array}{l}10,000- \\
300,000 \\
\text { nodes }\end{array}$ & PF - QSTS & & $\mathrm{T} \& \mathrm{D}$ & $\begin{array}{l}\text { Steady state } \\
\text { distribution and/or } \\
\text { transmission elements } \\
\text { with static control } \\
\text { characteristics } \\
\text { (including power } \\
\text { electronics-based } \\
\text { generations, } \\
\text { transformers, sources), } \\
\text { aggregations of loads } \\
\text { or by power } \\
\text { electronics } \\
\text { decoupling, may } \\
\text { include external } \\
\text { transmission system } \\
\text { and detail modeling of } \\
\text { some areas. } \\
\text { Chronology of control } \\
\text { actions should be } \\
\text { captured. }\end{array}$ \\
\hline $\begin{array}{l}\text { Resilience } \\
\text { studies } \\
\text { (e.g., black start, } \\
\text { degrade } \\
\text { gracefully, } \\
\text { islanding) }\end{array}$ & Time domain & $\begin{array}{l}\text { Can be in a } \\
\text { small or } \\
\text { large area } \\
\sim 1,000,000 \\
\text { s } \\
\text { nodes }\end{array}$ & $\begin{array}{l}\text { EMT (TS, } \\
\text { QSTS) }\end{array}$ & $\begin{array}{l}\text { Seconds to } \\
\text { hours }\end{array}$ & $\begin{array}{l}\text { QSTS may } \\
\text { be needed } \\
\text { for longer } \\
\text { durations } \\
\text { with EMT- } \\
\text { TS for } \\
\text { shorter } \\
\text { durations }\end{array}$ & $\begin{array}{l}\text { Three-phase EMT } \\
\text { models including } \\
\text { average-value models/ } \\
\text { detailed power } \\
\text { electronics models; } \\
\text { models of inductors, } \\
\text { transformer models, } \\
\text { etc. }\end{array}$ \\
\hline $\begin{array}{l}\text { Fast real-time } \\
\text { scheduling } \\
\text { (e.g., seconds } \\
\text { dispatches in } \\
\text { regions) }\end{array}$ & Phasor-domain & $\begin{array}{l}\text { Can be } \\
\text { large area } \\
\sim 1,000,000 \\
\mathrm{~s} \\
\text { nodes }\end{array}$ & $\begin{array}{l}\text { TS (PF, } \\
\text { QSTS) }\end{array}$ & $\begin{array}{l}\text { Seconds to } \\
\text { hours }\end{array}$ & $\begin{array}{l}\text { TS with } \\
\text { interactions } \\
\text { to quasi- } \\
\text { steady state } \\
\text { analysis }\end{array}$ & $\begin{array}{l}\text { Full three-phase with } \\
\text { new models to } \\
\text { represent the faster } \\
\text { scheduling. }\end{array}$ \\
\hline
\end{tabular}


Table ES-12. Summary of QSTS study requirements in future grids.

\begin{tabular}{|c|c|c|c|c|c|}
\hline Study-of-Interest & $\begin{array}{l}\text { Modeling } \\
\text { Domain }\end{array}$ & $\begin{array}{c}\text { Study System } \\
\text { Size }\end{array}$ & Timescales & $\begin{array}{c}\text { Cosimulatio } \\
n\end{array}$ & Model Requirements \\
\hline $\begin{array}{l}\text { Contingency analysis } \\
\text { (screening of all N-1, N- } \\
1-1 \text {, and selected N-k } \\
\text { (transmission) - } \\
\text { including converter } \\
\text { outages - could include } \\
\text { distributed slack bus) }\end{array}$ & $\begin{array}{l}\text { Phasor - } \\
\text { dc systems }\end{array}$ & $\begin{array}{l}\text { Can be large } \\
\sim 70,000- \\
100,000 \text { buses }\end{array}$ & $\begin{array}{l}\mathrm{PF}- \\
\text { representative } \\
\text { snapshots }\end{array}$ & $\mathrm{T} \& \mathrm{D}$ & $\begin{array}{l}\text { Steady state transmission } \\
\text { elements with static control } \\
\text { characteristics (including } \\
\text { power electronics-based } \\
\text { generations, transformers, } \\
\text { sources), aggregations of } \\
\text { loads or by power } \\
\text { electronics decoupling, } \\
\text { expanded detail in areas of } \\
\text { interest }\end{array}$ \\
\hline $\begin{array}{l}\text { Reliability analysis } \\
\text { (Composite transmission } \\
\text { / generation reliability } \\
\text { [adequacy] assessment } \\
\text { with power electronics } \\
\text { reliability) }\end{array}$ & $\begin{array}{l}\text { Phasor - } \\
\text { dc systems }\end{array}$ & $\begin{array}{l}\text { Can be large } \\
\sim 70,000- \\
100,000 \text { buses }\end{array}$ & $\begin{array}{l}\mathrm{PF}- \\
\text { representative } \\
\text { snapshots }\end{array}$ & T\&D & $\begin{array}{l}\text { Same as above }+ \text { power } \\
\text { electronics and system } \\
\text { elements reliability } \\
\text { characteristics }\end{array}$ \\
\hline $\begin{array}{l}\text { Distribution } \\
\text { reconfiguration } \\
\text { ( } \mathrm{N}-1 \text { and design of } \\
\text { reconfiguration } \\
\text { strategies) }\end{array}$ & $\begin{array}{l}\text { Three- } \\
\text { phase } \\
\text { unbalance } \\
d-d c \\
\text { systems }\end{array}$ & $\begin{array}{l}10,000 \text { buses } \\
\text { per feeder }\end{array}$ & $\begin{array}{l}\mathrm{PF}- \\
\text { representative } \\
\text { snapshots }\end{array}$ & $\mathrm{T} \& \mathrm{D}$ & $\begin{array}{l}\text { Steady state distribution } \\
\text { elements with static control } \\
\text { characteristics (including } \\
\text { power electronics-based } \\
\text { generations, transformers, } \\
\text { sources), aggregations of } \\
\text { loads or by power } \\
\text { electronics decoupling, } \\
\text { may include external } \\
\text { transmission system }\end{array}$ \\
\hline $\begin{array}{l}\text { Evaluation and design } \\
\text { of slow controls } \\
\text { (Transmission/subtransm } \\
\text { ission and/or distribution } \\
\text { analysis with high } \\
\text { penetration of DER - } \\
\text { combined ac and dc } \\
\text { analysis) }\end{array}$ & $\begin{array}{l}\text { Transmissi } \\
\text { on: Phasor } \\
- \text { dc } \\
\text { systems } \\
\text { Distributio } \\
\text { n: three- } \\
\text { phase } \\
\text { unbalance } \\
\text { d }- \text { dc } \\
\text { systems }\end{array}$ & $\begin{array}{l}10,000- \\
300,000\end{array}$ & PF - QSTS & $\mathrm{T} \& \mathrm{D}$ & $\begin{array}{l}\text { Steady state distribution } \\
\text { and/or transmission } \\
\text { elements with static control } \\
\text { characteristics (including } \\
\text { power electronics-based } \\
\text { generations, transformers, } \\
\text { sources), aggregations of } \\
\text { loads or by power } \\
\text { electronics decoupling, } \\
\text { may include external } \\
\text { transmission system and } \\
\text { detail modeling of some } \\
\text { areas } \\
\text { Chronology of control } \\
\text { actions should be captured }\end{array}$ \\
\hline $\begin{array}{l}\text { Short Circuit Analysis } \\
\text { (If response current } \\
\text { contributions from } \\
\text { power electronics is } \\
\text { known or standardized - } \\
\text { calculation of fault } \\
\text { currents in network) }\end{array}$ & $\begin{array}{l}\text { Short } \\
\text { circuit } \\
\text { static } \\
\text { model } \\
\text { capturing } \\
\text { current } \\
\text { contributio } \\
\text { ns }\end{array}$ & $\begin{array}{l}\text { Can be large } \\
\sim 70,000- \\
100,000 \text { buses }\end{array}$ & $\begin{array}{l}\text { Short circuit } \\
\text { model }\end{array}$ & $\begin{array}{l}\text { T\&D might } \\
\text { be useful }\end{array}$ & $\begin{array}{l}\text { Network impedances } \\
\text { distribution and/or } \\
\text { transmission elements with } \\
\text { fault current contribution } \\
\text { characteristics (including } \\
\text { power electronics-based } \\
\text { generations, transformers, } \\
\text { sources) }\end{array}$ \\
\hline
\end{tabular}


The operational characteristics and studies of future scenarios are summarized in Table ES-13.

Table ES-13. Summary of characteristics of operations and studies in future scenarios.

\begin{tabular}{|c|c|c|c|}
\hline Characteristics & Traditional Power System & $\begin{array}{c}\text { Intermediate Scenario: power } \\
\text { electronics \& Traditional } \\
\text { Components }\end{array}$ & $\begin{array}{c}\text { Long-Term Scenario: High- } \\
\text { Penetration Power } \\
\text { Electronics }\end{array}$ \\
\hline Power Dispatch & $\begin{array}{l}\text { Hourly dispatch, with real- } \\
\text { time market corrections } \\
\text { every } 15 \text { and } 5 \text { min (and in } 1 \\
\text { min under extreme } \\
\text { circumstances (e.g., CAISO) }\end{array}$ & $\begin{array}{l}\text { Faster dispatch of some resources } \\
\text { (approximately subminutes } \\
\text { interval), reversible power flow } \\
\text { from residential to distribution }\end{array}$ & $\begin{array}{l}\text { Faster dispatch feasible with } \\
\text { high penetration of power } \\
\text { electronics ( s or faster), } \\
\text { bidirectional power flow at } \\
\text { every layer (distribution- } \\
\text { transmission, residential- } \\
\text { distribution) }\end{array}$ \\
\hline \multirow[t]{2}{*}{ Dynamics } & $\begin{array}{l}\text { In minutes: Tap changers, } \\
\text { mechanically switched } \\
\text { capacitors, settings in } \\
\text { automatic voltage regulator } \\
\text { (AVR) }\end{array}$ & $\begin{array}{l}\text { In minutes/seconds: Some } \\
\text { portions of the system may } \\
\text { require shorter time scale } \\
\text { assessments due to high } \\
\text { penetration of power electronics } \\
\text { locally. Others may continue with } \\
\text { minutes-based dynamics } \\
\text { observed in tap changers, } \\
\text { mechanically switched } \\
\text { capacitors, etc. }\end{array}$ & $\begin{array}{l}\text { In seconds: Fast changing } \\
\text { power flows due to } \\
\text { variability (e.g., wind, PV) } \\
\text { and fasting acting devices } \\
\end{array}$ \\
\hline & $\begin{array}{l}\text { In seconds: Reactive power } \\
\text { flows, voltage controllers, } \\
\text { synchronous generators } \\
\text { Voltage variability in } \\
\text { distribution systems due to } \\
\text { DERs }\end{array}$ & $\begin{array}{l}\text { In seconds/milliseconds/ } \\
\text { microseconds: Depending upon } \\
\text { system metrics (like SCR, inertia, } \\
\text { power electronics penetration, } \\
\text { etc.), studies may need to be } \\
\text { performed in subseconds or } \\
\text { seconds range }\end{array}$ & $\begin{array}{l}\text { In milliseconds/ } \\
\text { microseconds/nanoseconds: } \\
\text { Dynamics of power } \\
\text { electronics will require } \\
\text { smaller time steps in } \\
\text { simulations }\end{array}$ \\
\hline
\end{tabular}


Table ES-13. Summary of characteristics of operations and studies in future scenarios (continued).

\begin{tabular}{|c|c|c|c|}
\hline Characteristics & Traditional Power System & $\begin{array}{l}\text { Intermediate Scenario: power } \\
\text { electronics \& Traditional } \\
\text { Components }\end{array}$ & $\begin{array}{c}\text { Long-Term Scenario: High- } \\
\text { Penetration Power } \\
\text { Electronics }\end{array}$ \\
\hline \multirow[t]{2}{*}{$\begin{array}{l}\text { Study } \\
\text { Footprints }\end{array}$} & $\begin{array}{l}\text { PF/QSTS/TS: Large system } \\
\text { studied using PF and TS } \\
\text { simulations. Small } \\
\text { distribution or } \\
\text { subtransmission networks } \\
\text { studied using QSTS. } \\
\text { Minimal real-time } \\
\text { simulations performed }\end{array}$ & $\begin{array}{l}P F / Q S T S / T S: \text { More transmission } \\
\text { and distribution studies using } \\
\text { PF/TS to study impact of } \\
\text { distributed generations and } \\
\text { controlled flow from power } \\
\text { electronics. More QSTS studies } \\
\text { to understand the impact of } \\
\text { variable generation and EV loads. } \\
\text { Online stability assessment } \\
\text { methods may use PF/TS for real- } \\
\text { time assessments }\end{array}$ & $\begin{array}{l}\text { PF/QSTS/TS: Increased } \\
\text { penetration of power } \\
\text { electronics requires larger } \\
\text { transmission-distribution } \\
\text { studies with QSTS to study } \\
\text { worst-case scenarios. TF } \\
\text { studies may be performed on } \\
\text { transmission-distribution } \\
\text { systems. Online stability } \\
\text { assessment methods to use } \\
\text { PF/TS for real-time } \\
\text { assessments }\end{array}$ \\
\hline & $\begin{array}{l}\text { EMT: Small systems like } \\
\text { substations, insulation } \\
\text { coordination, } \\
\text { subsynchronous oscillations } \\
\text { studied in EMT. Real-time } \\
\text { EMT and component } \\
\text { simulations performed to } \\
\text { evaluate device-under-test } \\
\text { performance with smaller } \\
\text { systems }\end{array}$ & $\begin{array}{l}\text { EMT: Larger system studies (like } \\
\text { small-scale transmission network } \\
\text { with detailed distribution } \\
\text { networks or a portion of } \\
\text { transmission networks) in EMT } \\
\text { to understand local control } \\
\text { interactions, large-scale } \\
\text { disturbance impact related } \\
\text { reliability studies. HIL studies } \\
\text { and online assessments to use } \\
\text { real-time or faster-than-real-time } \\
\text { EMT simulations with larger } \\
\text { systems }\end{array}$ & $\begin{array}{l}\text { EMT: Largest footprint of } \\
\text { EMT studies than today's or } \\
\text { intermediate studies (like } \\
\text { large-scale transmission } \\
\text { networks or a combination of } \\
\text { medium-scale transmission } \\
\text { network with detailed } \\
\text { distribution networks) to } \\
\text { understand stability and } \\
\text { reliability of systems. HIL } \\
\text { studies and online } \\
\text { assessments to use real-time } \\
\text { or faster-than-real-time EMT } \\
\text { simulations with largest } \\
\text { footprint of systems }\end{array}$ \\
\hline \multirow[t]{2}{*}{$\begin{array}{l}\text { Distribution/ } \\
\text { Customer } \\
\text { Systems }\end{array}$} & $\begin{array}{l}\text { Load Models in } \\
\text { Transmission Studies: } \\
\text { Aggregated for transmission } \\
\text { studies } \\
\text { (e.g., composite load } \\
\text { modeling, aggregated DER } \\
\text { models emerging) } \\
\text { Gaps: ES and wind as DERs }\end{array}$ & $\begin{array}{l}\text { Distribution Systems in } \\
\text { Transmission Studies: Integrated } \\
\text { studies of transmission- } \\
\text { distribution systems with } \\
\text { DERs/ES/EV/power electronics } \\
\text { loads in locations with high } \\
\text { penetration of power electronics }\end{array}$ & $\begin{array}{l}\text { Distribution System in } \\
\text { Transmission Studies: } \\
\text { Possibility for sections of } \\
\text { transmission-distribution } \\
\text { systems to be decoupled for } \\
\text { PF studies (with minimal } \\
\text { power exchange between } \\
\text { asynchronous/fractal } \\
\text { systems). Detailed } \\
\text { distribution system models in } \\
\text { dynamics with } \\
\text { DERs/ES/EV/power } \\
\text { electronics loads }\end{array}$ \\
\hline & $\begin{array}{l}\text { Distribution Studies: } \\
\text { Transmission assumed as } \\
\text { ideal sources in distribution } \\
\text { studies }\end{array}$ & $\begin{array}{l}\text { Distribution Studies: Fidelity of } \\
\text { combined machine and power } \\
\text { electronics load models need to } \\
\text { be identified and used in } \\
\text { transmission-distribution studies }\end{array}$ & $\begin{array}{l}\text { Distribution Studies: Fidelity } \\
\text { of power electronics loads } \\
\text { and their interaction with } \\
\text { other power electronics needs } \\
\text { to be assessed and used in } \\
\text { transmission-distribution } \\
\text { studies }\end{array}$ \\
\hline
\end{tabular}




\subsection{STANDARDS SUMMARY}

Standards applicable to future grids with increased penetration of power electronics are summarized in Table ES-14. The standards indicate the trend of high-fidelity modeling and EMT simulations of larger systems, as maybe noted in the recent ongoing developments in Institute of Electrical and Electronics Engineers (IEEE) P2800, IEEE/CIGRE B4-82, CIGRE C4-56, to name a few. Other standards, such as IEEE 519, IEEE 1547.7, IEEE 3002.2, and IEEE 1159, help define the study requirements for future grids and the type of simulations considered in this report. Details about power electronics systems and their characteristics can be found in standards like IEEE 1662, IEEE 1676, among others.

Table ES-14. Summary of standards applicable to future grids.

\begin{tabular}{|c|c|c|}
\hline Standard & Name & Key Points Related to this Study \\
\hline IEEE Std. 1662 & $\begin{array}{l}\text { IEEE Recommended Practice for } \\
\text { the Design and Application of } \\
\text { Power Electronics in Electrical } \\
\text { Power Systems }\end{array}$ & $\begin{array}{l}\text { Power electronics equipment studies needed } \\
\text { (power balance, thermal management, transients, } \\
\text { dynamic performance) } \\
\text { - Duration and time step for studies } \\
\text { - Types of power electronics equipment models } \\
\text { needed }\end{array}$ \\
\hline IEEE Std 1676 & $\begin{array}{l}\text { IEEE Guide for Control } \\
\text { Architecture for High Power } \\
\text { Electronics (1 MW and Greater) } \\
\text { Used in Electric Power } \\
\text { Transmission and Distribution } \\
\text { Systems }\end{array}$ & $\begin{array}{l}\text { - Power electronics equipment hierarchical } \\
\text { control standards } \\
\text { - Functionalities of each control stage and time } \\
\text { step } \\
\text { - Study requirements }\end{array}$ \\
\hline IEEE Std 1159 & $\begin{array}{l}\text { IEEE Recommended Practice for } \\
\text { Monitoring Electric Power Quality }\end{array}$ & - Define conducted electromagnetic phenomena \\
\hline IEEE Std 519 & $\begin{array}{l}\text { IEEE Recommended Practice and } \\
\text { Requirements for Harmonic Control } \\
\text { in Electric Power Systems }\end{array}$ & $\begin{array}{ll}\text { - Harmonic standards for equipment (including } \\
\text { power electronics) } \\
\text { - Study requirements }\end{array}$ \\
\hline IEEE Std 1547.7 & $\begin{array}{l}\text { IEEE Guide for Conducting } \\
\text { Distribution Impact Studies for } \\
\text { Distributed Resource } \\
\text { Interconnection }\end{array}$ & $\begin{array}{l}\text { Different types of simulations defined: power } \\
\text { flow, quasi static simulation (QSS/QSTS), } \\
\text { dynamic simulation (TS), electromagnetic } \\
\text { transient simulation (EMT) for distribution } \\
\text { systems }\end{array}$ \\
\hline IEEE Std 3002.2 & $\begin{array}{l}\text { IEEE Recommended Practice for } \\
\text { Conducting Load-Flow Studies } \\
\text { and Analysis of Industrial and } \\
\text { Commercial Power Systems }\end{array}$ & $\begin{array}{l}\text { - QSTS definition for transmission systems } \\
\text { - } \quad \text { Study needs identified and defined } \\
\text { Computational challenges and data requirements } \\
\text { for QSTS identified }\end{array}$ \\
\hline IEEE P2800 & $\begin{array}{l}\text { Standard for Inverter-Based } \\
\text { Resources Connecting to the BPS }\end{array}$ & $\begin{array}{l}\text { NERC follow-up from reliability concerns } \\
\text { identified with inverter-based resources }\end{array}$ \\
\hline IEEE/CIGRE B4-82 & $\begin{array}{l}\text { Guidelines for Use of Real-Code in } \\
\text { EMT Models for HVDC, FACTS } \\
\text { and inverter-based generators in } \\
\text { Power Systems Analysis }\end{array}$ & $\begin{array}{l}\text { - Real code usage for control systems in power } \\
\text { electronics equipment } \\
\text { - Use of switched system model of power } \\
\text { electronics equipment }\end{array}$ \\
\hline CIGRE C4-56 & $\begin{array}{l}\text { Electromagnetic transient } \\
\text { simulation models for large-scale } \\
\text { system impact studies in power } \\
\text { systems having a high penetration } \\
\text { of inverter connected generation }\end{array}$ & $\begin{array}{l}\text { - } \quad \text { Support large-scale EMT simulations } \\
\text { - } \quad \text { Develop standards for models } \\
\text { - } \quad \text { Increasing trend to use EMT simulations } \\
\text { Computational challenges identified }\end{array}$ \\
\hline
\end{tabular}




\section{FUTURE GRID SIMULATION GAPS}

Based on the characteristics of existing tools, studies performed with them, and the required tool characteristics needed to study future scenarios of the grid, gaps are identified for each simulator and are presented in the following subsections.

\subsection{DYNAMIC SIMULATOR CHARACTERISTICS}

The characteristics of existing dynamic simulators are shown in Figure ES-7 (Current). The range of numbers provided for each characteristic is based on the different studies that have been completed with each simulator. The requirements from the dynamic real-time simulators to study future scenarios of the grid are also shown in Figure ES-7 (Future). The range of numbers provided for each characteristic reflects the different study systems considered in future scenarios. For example, in the intermediate scenario, study systems may include $50 \%$ penetration of power electronics in local/regional grids that may represent $10-100 \%$ of the interconnection. Similar case studies can also be considered for the longterm scenarios. These study systems in the two scenarios result in the range observed in the characteristics of the dynamic simulators required to study future scenarios grids in Figure ES-7. From Figure ES-7, the trends of requirements in dynamic simulators to study future scenarios of grids include reduced time steps, increased number of states that need to be simulated, and reduced time taken to simulate. For component simulators, increased duration of simulations are also required. These changes are needed because of the future grid scenarios and the high-fidelity models being considered (Section 3 ).

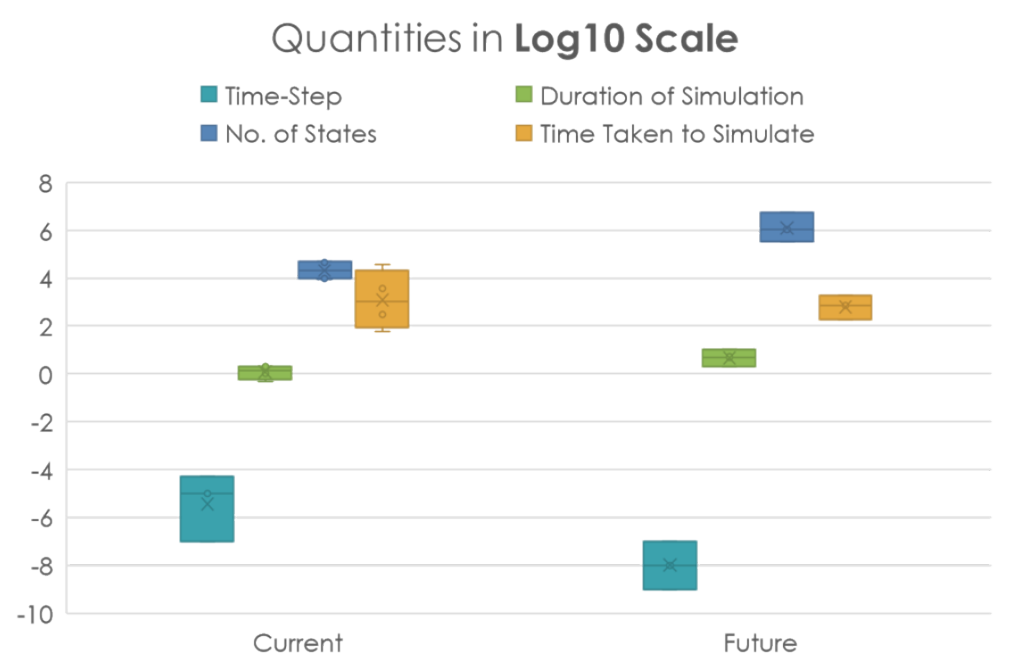

(a) Component Simulators 


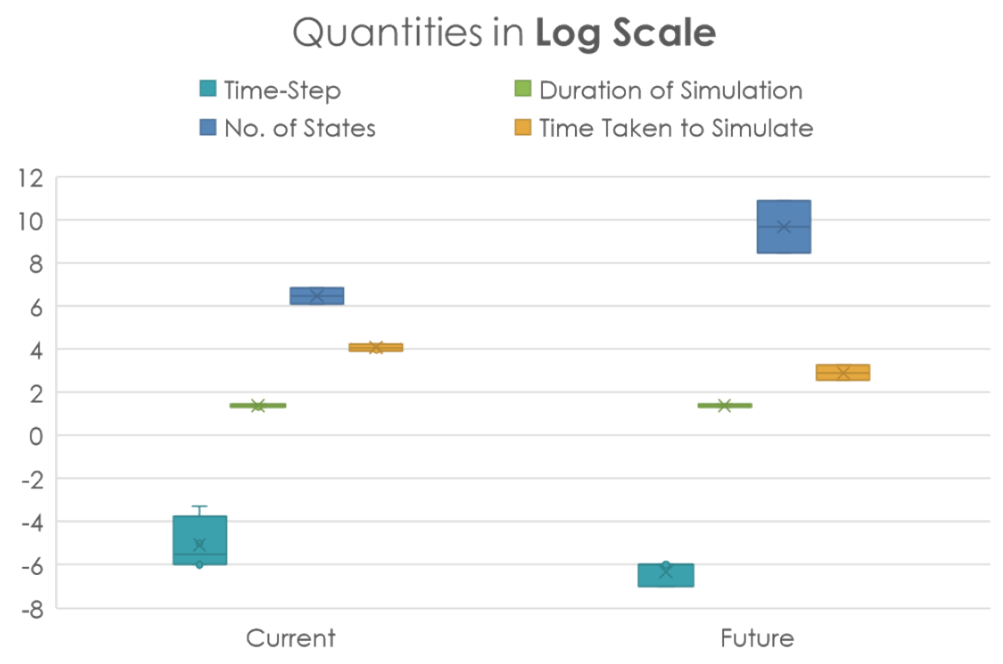

(b) EMT Simulators

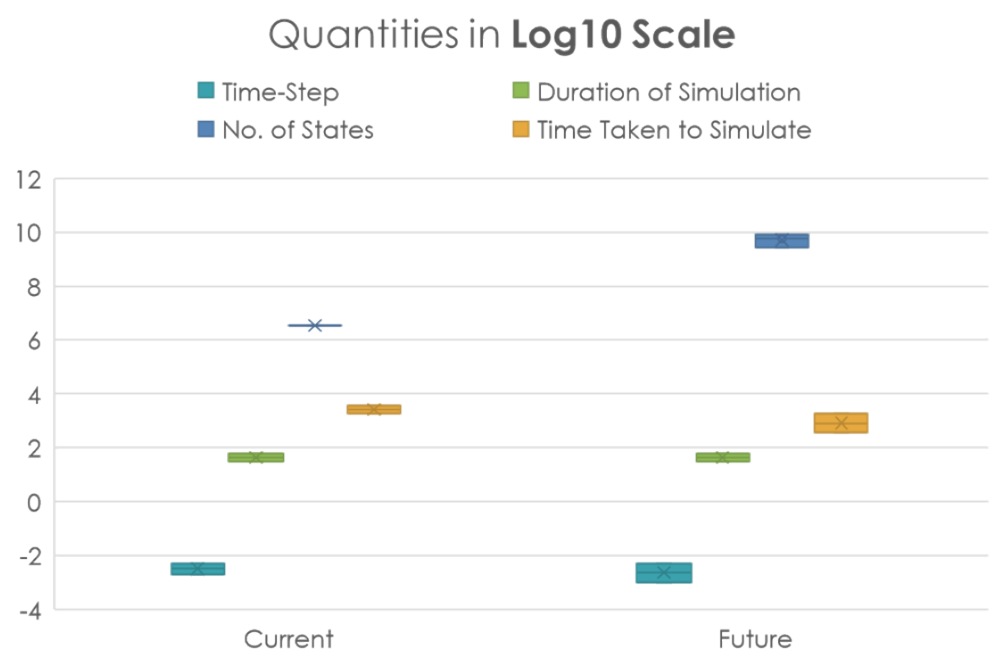

(c) TS Simulators

Figure ES-7. Characteristics of existing dynamic simulators (Current) and the required characteristics in future dynamic simulators (Future).

The characteristics of existing dynamic real-time simulators are shown in Figure ES-8 (Current). The requirements from the dynamic real-time simulators to study future scenarios of the grid are also shown in Figure ES-8 (Future). The range observed in Figure ES-8 is due to the same reason mentioned earlier for dynamic simulators. From Figure ES-7, the trends of requirements in dynamic simulators to study future scenarios of grids include reduced time steps, increased number of states per unit that need to be simulated, and increased total number of states. These changes are needed because of the future grid scenarios and the high-fidelity models being considered (Section 3). 


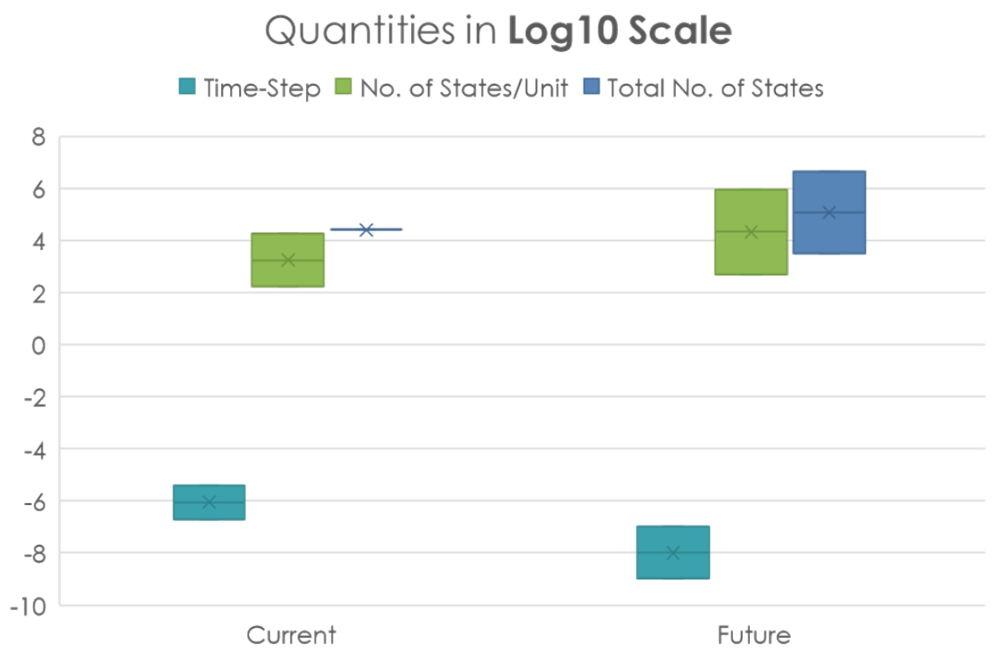

(a) Component Simulators

\section{Quantities in Log10 Scale}

$\square$ Time-Step $\square$ No. of States/Unit $\square$ Total No. of States

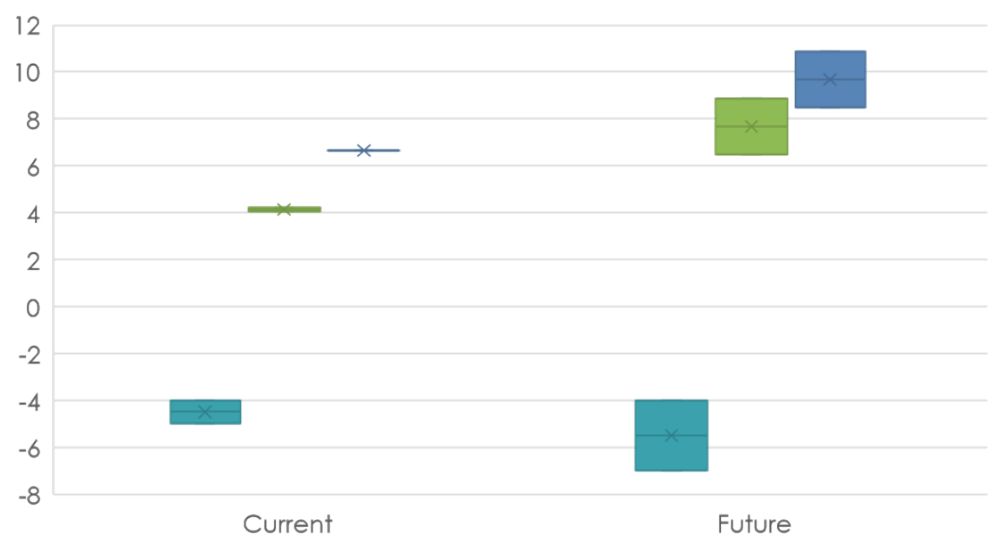

(b) EMT Simulators 


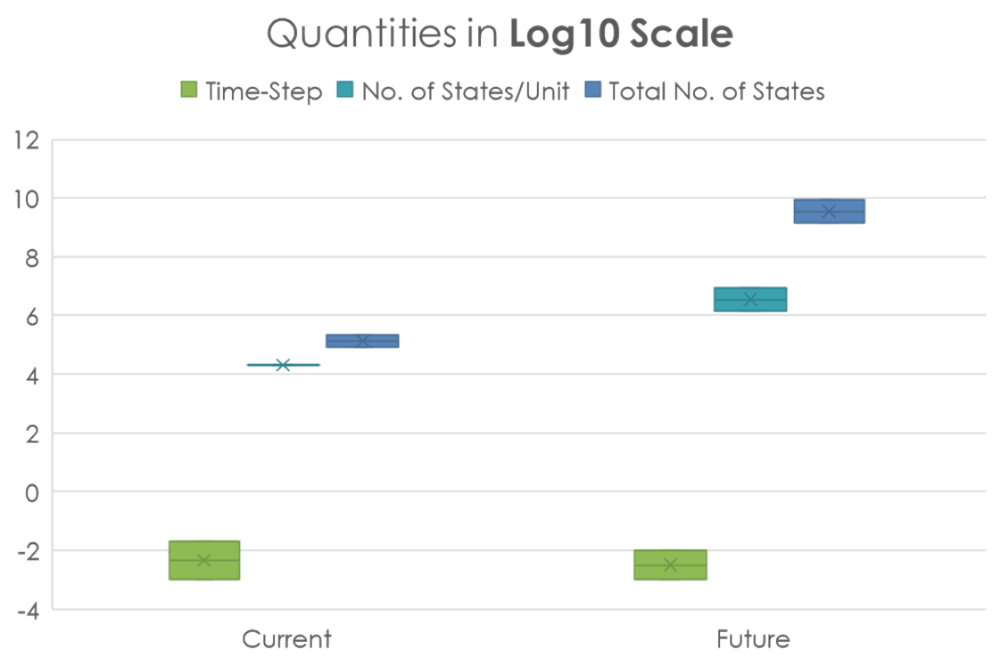

(c) TS Simulators

Figure ES-8. Characteristics of existing dynamic real-time simulators (Current) and the required characteristics in future dynamic real-time simulators (Future).

\subsection{STEADY-STATE SIMULATOR CHARACTERISTICS}

The characteristics of existing power flow simulators are shown in Figure ES-9 (Current). The requirements from the power flow simulators to study future scenarios of the grid are also shown in Figure ES-9 (Future). The range observed in Figure ES-9 results from the different percentage of transmission loads modeled using distribution system networks. The range considered varies from 5 to $10 \%$ of transmission loads in EI-ERCOT-WI interconnected grids. From Figure ES-9(a), the trends of requirements in power flow simulators to study future scenarios of grids include increased number of states. The corresponding trends observed in QSTS simulators are increased number of states and reduced time steps. These changes are needed because of the future grid scenarios and the high-fidelity models being considered (Section 3).

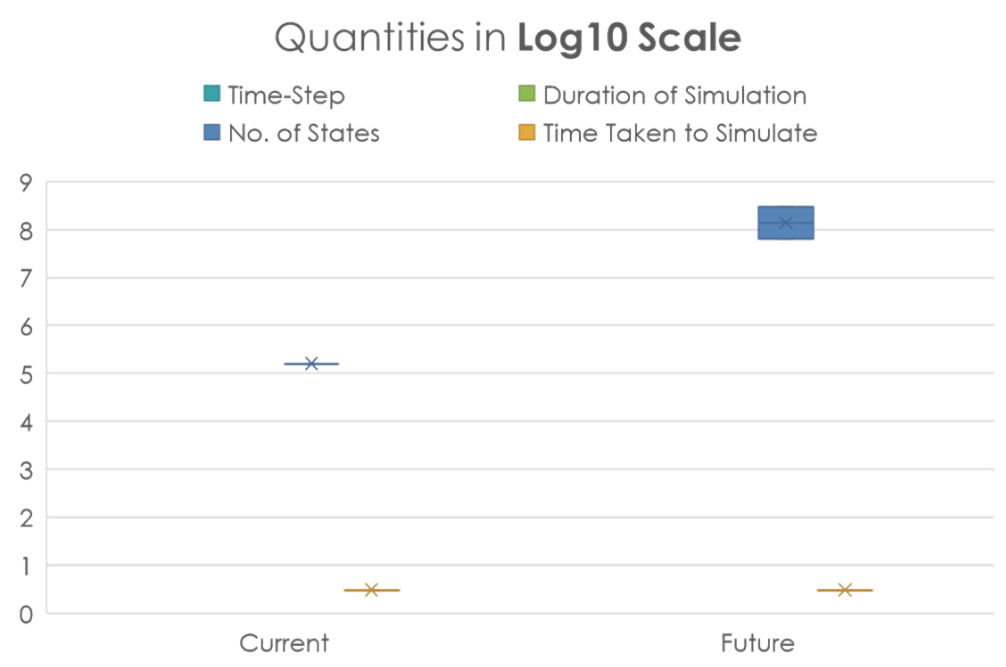

(a) Power Flow Simulators 


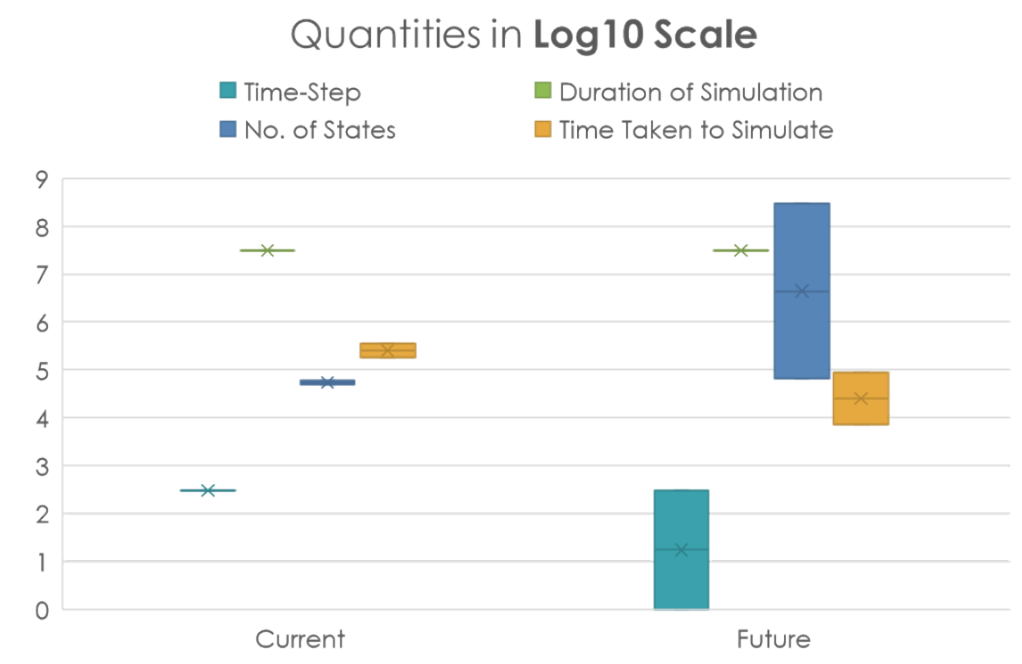

(b) QSTS Simulators

Figure ES-9. Characteristics of existing steady-state simulators (Current) and the required characteristics in future steady-state simulators (Future).

The characteristics of existing QSTS real-time simulators are shown in Figure ES-10 (Current). The requirements from the QSTS real-time simulators to study future scenarios of the grid are also shown in Figure ES-10 (Future). The range observed in Figure ES-10 is due to the same reason mentioned earlier for steady-state simulators. From Figure ES-10, the trends observed in QSTS simulators are increased number of states and reduced time steps. These changes are needed because of the future grid scenarios and the high-fidelity models being considered (Section 3).

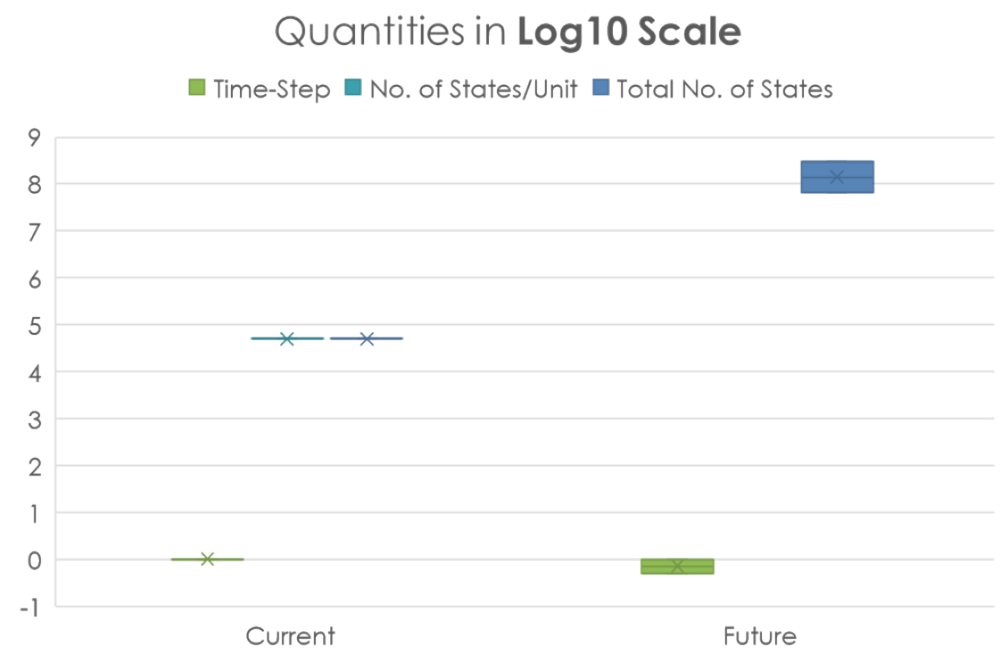

Figure ES-10. Characteristics of existing QSTS real-time simulators (Current) and the required characteristics in future QSTS real-time simulators (Future).

\subsection{SUMMARY OF GAPS AND FINDINGS}

From the characteristics identified in simulators and real-time simulators, the gaps identified in the simulators are summarized in Figure ES-11. The gaps in simulators identified include the requirement of decreased time-steps, increased number of states to be simulated, and decreased time taken to simulate. These gaps indicate the need for increased computing resources and efficient algorithms to simulate 
future scenarios of grids. The gaps in real-time simulators identified include the decreased time-steps, increased number of states per unit, and increased total number of states. These gaps indicate the need for research into computing architectures and algorithms that enable the real-time simulation of future scenarios of grids. Specific set of recommendations are providing in the next section.

\section{Gaps: Multiple of Current Generation Status (in Log10 scale)}

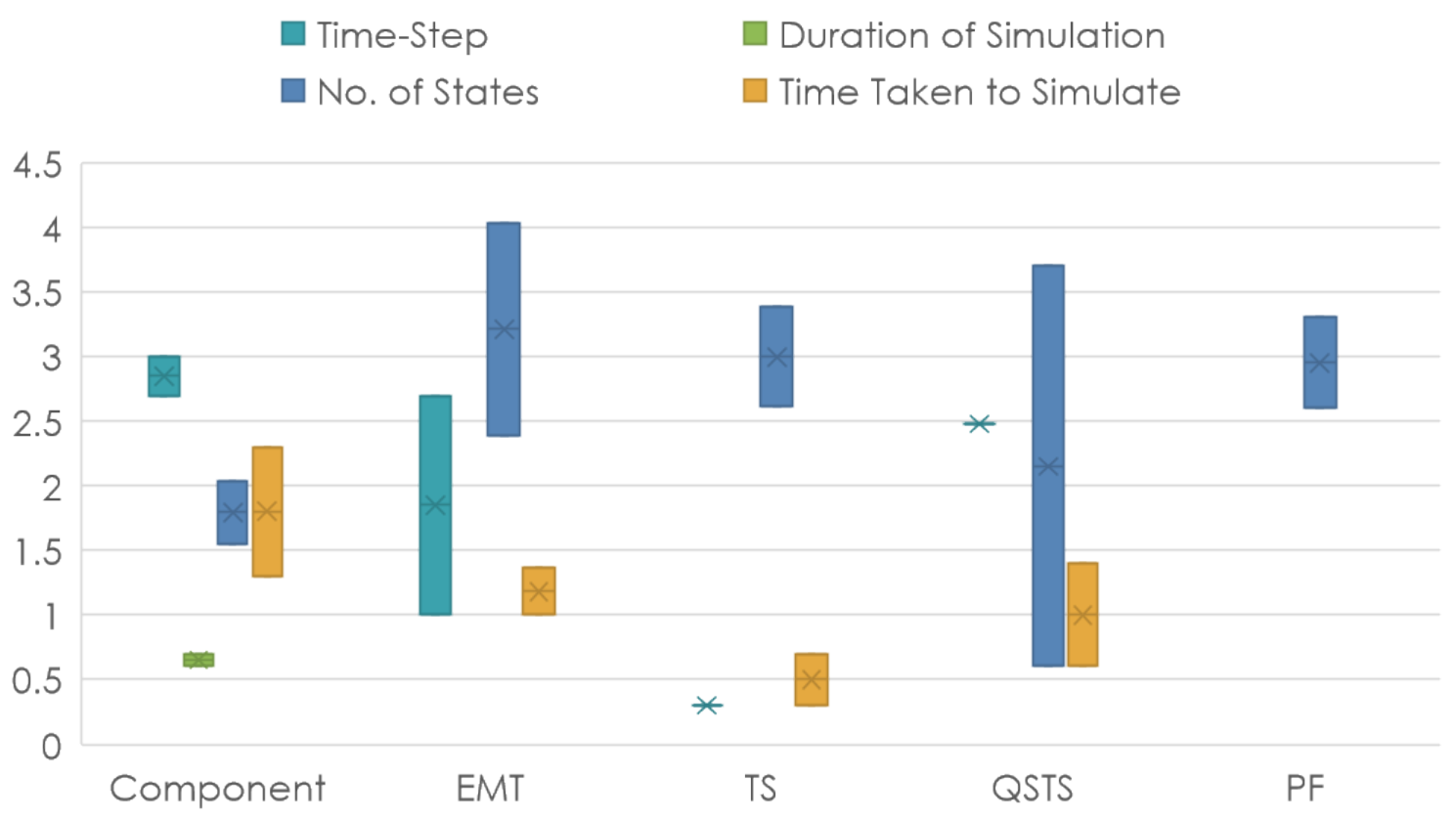

(a) Simulators 


\section{Gaps: Multiple of Current Generation Status (in Log10 scale)}

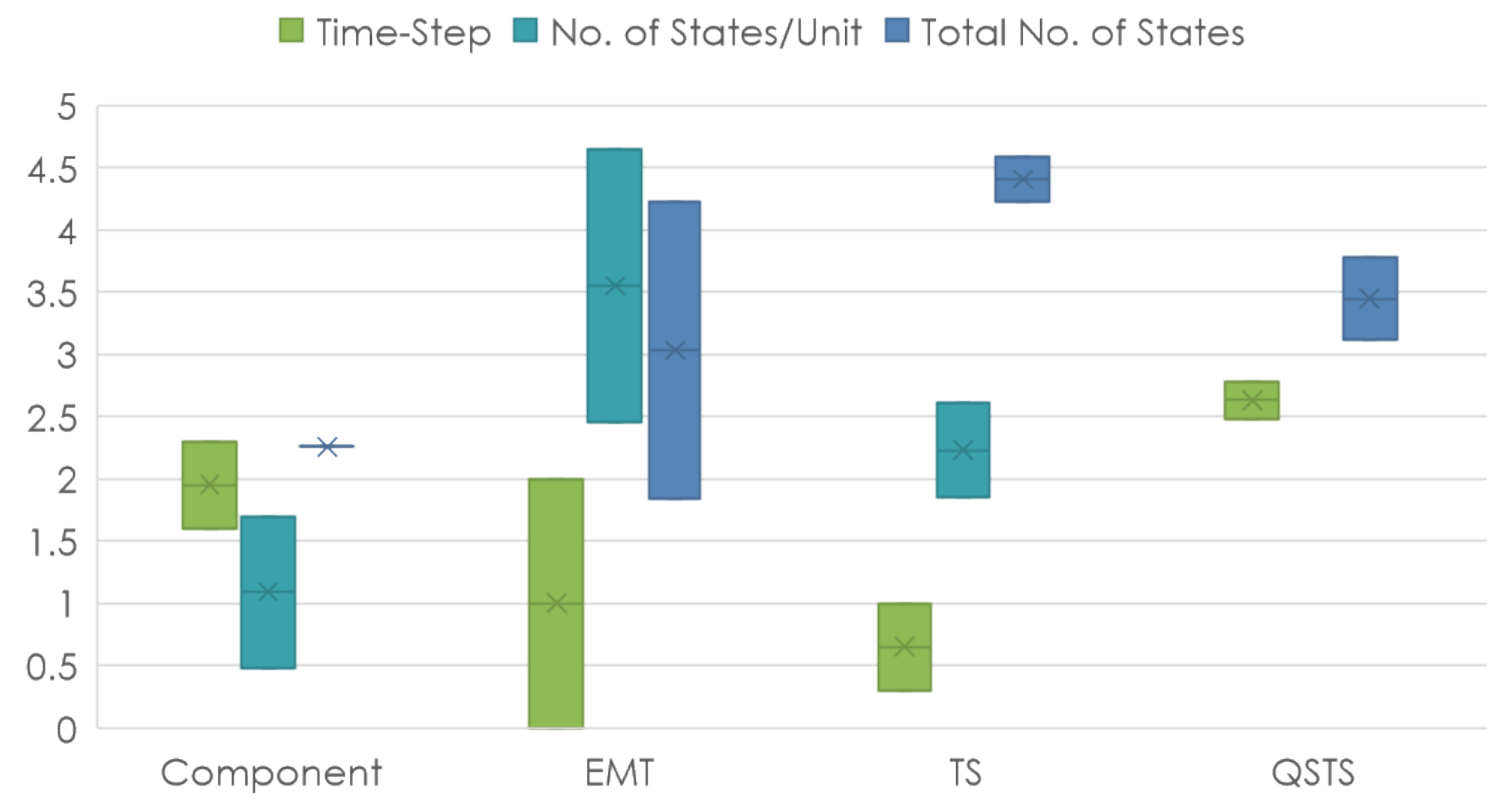

(b) Real-time Simulators

Figure ES-11. Summary of gaps in simulators to simulate grids with high penetration of power electronics.

\section{RESEARCH QUESTIONS AND RECOMMENDATIONS}

Based on the gaps identified in Section 4 and the analysis performed in Sections 2 and 3, the following research questions were identified:

- How can simulation of large area EMT models be performed with more complex and faster acting power electronics in a reasonable time? The large area may result from simulation of transmissiondistribution grids or larger transmission grids.

- What should be the boundaries of EMT and TS simulations for high penetration of power electronics?

- How can simulation of large-scale EMT-TS models be performed in reasonable time?

- How can multidomain simulations (e.g., Component-EMT-TS-QSTS) be performed in a reasonable time?

- How can convergence be achieved of ac-dc or T\&D systems' power flow and QSTS algorithms with minimal iterations to solve in a reasonable timeframe?

- With the evolution of grid and computing upgrades, can the QSTS and power flow simulator's performance objectives be upgraded? For example, can one of the NERC requirements to perform contingency analysis in every 30 min be upgraded? 
- When should QSTS simulations be performed? Which grids (e.g., transmission, subtransmission, distribution grids) need QSTS studies? What simulation parameters (e.g., time steps) are needed to perform these studies? Can these studies be standardized?

- What new computing architectures can be leveraged for large area high-fidelity dynamic real-time simulations?

- What algorithms can enable large number of multicore or GPU-based implementations of real-time simulations?

- What are the newer hardware architectures that can enable faster emulation capabilities?

- How can machine learning techniques be leveraged to improve the existing simulation capabilities?

In addition to the research questions identified above, the following set of recommendations are provided for dynamic simulators:

- Recommendation 1: Modeling improvements are needed in current generation of simulators. For example, grid-forming inverter models of hybrid PV-ESS, ESS, wind-PV, etc. are needed to be included in existing simulators. Standardizing links between different simulator domains (e.g., EMTTS, EMT-Component, etc.) is needed.

- Recommendation 2: Several orders-of-magnitude improvement is needed in dynamic simulators (EMT, components) to enable planning and operation of future electric grids with high penetration of power electronics. The simulators include capability to cosimulate dynamics in different timescales (e.g., component, EMT, TS, QSTS) or T\&D system dynamics. The simulations need to exploit the multithread/core capability of emerging computing solutions and be cost-effective. Potential solutions could be used for real-time DSA.

- Recommendation 3: Intelligence and enhanced automation capability needs to be embedded within simulators to provide the capability to simulate higher fidelity models in future electric grids within reasonable timeframes and with minimal human intervention.

- Recommendation 4: Adaptive simulators that switch between dynamic simulators, QSTS simulators, or a combination of both need to be developed. For example, in [78], adaptive simulator that switches between QSTS and TS simulators has been developed.

- Recommendation 5: Early-stage research is needed on algorithms and applied mathematics to simulate dynamics on new computing architectures (like quantum computing, neuromorphic computing) that may provide leap-of-faith benefits in simulating higher fidelity of component models and larger size of grids.

The following recommendations are provided for steady-state simulators:

- Recommendation 6: Power flow algorithms for ac-dc or T\&D systems are needed in scenarios with increased dc systems and with high penetration of power electronics.

- Recommendation 7: High-performance computing (HPC) power flow algorithms are needed for faster convergence between studies. The HPC algorithms are needed for large-scale contingency analysis that includes multiple power flow runs and postprocessing. These algorithms need to meet the NERC 
requirement for contingency analysis based on real-time operating points every $30 \mathrm{~min}$ by transmission owners and reliability coordinators.

- Recommendation 8: New system strength metrics and short circuit calculation algorithms are needed for high penetration of power electronics. These algorithms would serve as the preliminary screening for further dynamic study needs.

- Recommendation 9: Modeling approaches and algorithms for accurately capturing and testing power electronics control functions (slow evolving control) in QSTS algorithms are needed for areas with high power electronics penetration. The functions include voltage control in ac and dc systems with variable generation. This formulation should enable capability to study local and interarea coordination of resources including renewables and energy storage. Large-scale QSTS simulation algorithms for studying regional grids and interconnections with high penetration of power electronics are needed. T\&D system's QSTS simulation algorithms are needed with increased penetration of DERs. Standardization of studies performed with QSTS simulations are needed.

The following recommendations are provided for dynamic and steady-state real-time simulators:

- Recommendation 10: Research is needed on computing architectures and designs that enable realtime simulation of high-fidelity power electronics and EMT simulation of large grids.

- Recommendation 11: Research is needed on algorithms and applied mathematics that enable EMT simulations of large grids in real-time in new computing architectures and designs.

- Recommendation 12: Research is needed on algorithms and applied mathematics that enable cosimulations (EMT, TS) of grids over a long period in real-time in new computing architectures and designs. Evaluate the need for QSTS in future grids, especially for very large systems (e.g., T\&D of EI, WI, ERCOT).

- Recommendation 13: Research is needed on high-bandwidth emulators (that includes an improvement by an order of at least 10) that can capture fast transients in the grid and power electronics without instability caused by the delay in the response of the current generation of emulators.

Final recommendations are provided here:

- Recommendation 14: Data collection from components (like plants) and structuring the data for information to be used by simulators is needed. Translation of data from one simulator to another needs to be standardized and considered.

- Recommendation 15: Model validation and verifications for next-generation high-fidelity component models is needed.

\section{ACKNOWLEDGMENTS}

The authors would like to acknowledge the support and feedback from Kerry Cheung (US Department of Energy), Madhu Chinthavali (ORNL), and the industry advisory board (IAB) participants.

The authors would like to also thank the participants of the industry advisory board: Jiuping Pan and Renaldo Nuqui (Asea Brown Boveri [ABB]), Ebrahim Rahimi (CAISO), Kevin Chamberlain (Commonwealth Edison [ComEd]), Jose Conto (Electric Reliability Council of Texas [ERCOT]), Sharma 
Kolluri (Entergy), Andrew Arana (Florida Power \& Lighting [FPL]), Siddharth Pant (General Electric [GE]), Steve Malek and Matt Lee (Great River Energy), Armando Figueroa-Acevedo and Nihal Mohan and Jordan Bakke and Warren Hess (Midcontinent ISO [MISO]), Babak Enayati (National Grid), Steven Judd (New England ISO [NE-ISO]), Mark Ahlstrom (Next Era Analytics), Austin White (Oklahoma Gas \& Electric [OGE]), Hassan Ghoudjehbaklou (San Diego Gas and Electric [SDG\&E]), Sergey Kynev (Siemens), Amos Ang and Md Arifujjaman (Southern California Edison [SCE]), Stephen Kelley (Southern Company), Harvey Scribner (Southwest Power Pool [SPP]), Lina He (University of Illinois at Chicago [UIC]), Alireza Ghassemian (US Department of Energy), James Hirning (Western Area Power Administration [WAPA]).

\section{REFERENCES}

[1] MIGRATE project, https://www.h2020-migrate.eu/.

[2] RESERVE project, http://www.re-serve.eu/.

[3] National Science Foundation (NSF) Workshop, "Power Electronics-Enabled Operation of Power Systems," http://peac.ece.iit.edu/events/nsf-workshop-on-power-electronics-enabled-operation-ofpower-systems/.

[4] US Department of Energy Solar Energy Technologies Office, "Grid-Forming Inverters for LowInertia Power Systems."

[5] N. Mohan, W. Hess, and J. Bakke, "Renewable Integration Impact Assessment: Finding Integration Inflection Points of Increasing Renewable Energy, Operating Reliability Dynamics Results up to 40\%," Midcontinent Independent System Operator (MISO) webinar, 2019, https://cdn.misoenergy.org/20190716\%20RIIA\%20Workshop\%20Dynamics\%20Studies\%20Resul ts442568.pdf.

[6] J. Tanner, D. Bowman, H. Scribner, S. Jordan, B. Hentschel, S. Arabi, F. Howell, D. Ramasubramanian, E. Farantatos, A. Gaikwad, and D. Brown, SPP 2019 Inverter Based Generation Integration Study (IBIS), SPP report, 2019.

[7] I. Green, "CAISO Experience with Impact of High Penetration Of Renewable Resources on ShortTerm Voltage Stability," 2015 IEEE Power and Energy Society General Meeting, Denver, CO, 2015, pp. 1-18.

[8] N. W. Miller, S. Pajic, and K. Clark, Concentrating Solar Power Impact on Grid Reliability, National Renewable Energy Laboratory Report, 2018.

[9] K. Clark, N. W. Miller, M. Shao, S. Pajic, and R. D'Aquila, "Transient Stability of the US Western Interconnection with High Wind and Solar Generation," 2015 IEEE Power and Energy Society General Meeting, Denver, CO, 2015, pp. 1-5.

[10] S. You et al., "Comparative Assessment of Tactics to Improve Primary Frequency Response Without Curtailing Solar Output in High Photovoltaic Interconnection Grids," IEEE Transactions on Sustainable Energy, vol. 10, no. 2, pp. 718-728, April 2019.

[11] S. You et al., "Impact of High PV Penetration on the Inter-Area Oscillations in the U.S. Eastern Interconnection," in IEEE Access, vol. 5, pp. 4361-4369, 2017.

[12] G. Kou, M. Till, T. Bilke, S. Hadley, Y. Liu, and T. King, "Primary Frequency Response Adequacy Study on the U.S. Eastern Interconnection Under High-Wind Penetration Conditions," IEEE Power and Energy Technology Systems Journal, vol. 2, no. 4, pp. 125-134, Dec. 2015. 
[13] Y. Liu, S. You, J. Tan, Y. Zhang, and Y. Liu, "Frequency Response Assessment and Enhancement of the U.S. Power Grids Toward Extra-High Photovoltaic Generation Penetrations-An Industry Perspective," IEEE Transactions on Power Systems, vol. 33, no. 3, pp. 3438-3449, May 2018.

[14] K. Creighton, M. McClure, R. Skillen, J. O’Higgins, T. McCartan, and A. Rogers, "Increased Wind Generation in Ireland and Northern Ireland and the Impact on Rate of Change of Frequency," EirGrid, 2014.

[15] R. Fan, M. A. Elizondo, H. Kirkham, J. Lian, F. Wilches-Bernal, and D. Schoenwald, "Oscillation Damping Control Using Multiple High Voltage DC Transmission Lines: Controllability Exploration," 2018 IEEE/PES Transmission and Distribution Conference and Exposition (T\&D), Denver, CO, 2018, pp. 1-9.

[16] S. Hwang, M. Yoon, and G. Jang, "Evaluation of STATCOM Capacity on Transient Stability in Jeju-Island System with HVDC and Wind Farms," 2015 9th International Conference on Power Electronics and ECCE Asia (ICPE-ECCE Asia), Seoul, 2015, pp. 367-372.

[17] A. A. van der Meer, M. Ndreko, J. A. Bos, M. Gibescu, M. A. M. M. van der Meijden, and W. L. Kling, "Stability Assessment of VSC-HVDC Connected Large-Scale Offshore Wind Power: A North-Sea Region Case Study,” 2015 IEEE Eindhoven PowerTech, Eindhoven, 2015, pp. 1-6.

[18] North American Electric Reliability Corporation (NERC) and Western Electricity Coordinating Council (WECC), 1,200 MW Fault Induced Solar Photovoltaic Resource Interruption Disturbance Report, NERC and WECC Staff Report, 2017.

[19] North American Electric Reliability Corporation (NERC) and Western Electricity Coordinating Council (WECC), "900 MW Fault Induced Solar Photovoltaic Resource Interruption Disturbance Report," NERC and WECC Staff Report, 2018.

[20] North American Electric Reliability Corporation (NERC) and Western Electricity Coordinating Council (WECC), "April and May 2018 Fault Induced Solar Photovoltaic Resource Interruption Disturbances Report,” NERC and WECC Staff Report, 2019.

[21] M. Behnke, G. Custner, E. Farantatos, N. Fischer, R. Guttromson, A. Isaacs, R. Majumder, S. Pant, M. Patel, R. Quint, V. Reddy Konala, and I. Voloh, Impact of Inverter-Based Resource NegativeSequence Current Injection on Transmission System Protection, Sandia Report, 2020.

[22] US Department of Energy SETO FOA, "Advanced Systems Integration for Solar Technologies (ASSIST): Situational Awareness and Resilient Solutions for Critical Infrastructure", 2019, https:/www.energy.gov/eere/solar/seto-fy2019-advanced-solar-systems-integration-technologies.

[23] US Department of Energy SETO FOA, "SETO FY2019 - Advanced Solar Systems Integration Technologies," 2019, https://www.energy.gov/eere/solar/advanced-systems-integration-solartechnologies-assist-situational-awareness-and.

[24] B. Marszalkowski, and A. Isaacs, "New England DG Bulk Grid Impact EMT Study," North American Electric Reliability Corporation Inverter-Based Resource Performance Task Force, 2019.

[25] A. Dissanayaka, J. Wiebe, and A. Isaacs, "Panhandle and South Texas Stability and System Strength Assessment," ERCOT Report, 2018.

[26] Ranil de Silva, "Review of AEMO's PSCAD Modelling of the Power System in South Australia," Power Systems Consultants Report, 2017.

[27] US Department of Energy Wind Energy Technologies Office Projects, https://www.energy.gov/eere/wind/wind-energy-technologies-office-projects-map.

[28] S. Debnath, M. S. Chinthavali, J. Sun, P. R. V. Marthi, S. Chinthavali, S. Lee, M. Elizondo, Y. Markarov, Q. Huang, M. Vellam, Y. Liu, A. Tbaileh, Q. Zhang, N. Samaan, H. Kirkham, J. 
Novacheck, and J. Lau, Models and Methods for Assessing the Value of Hvdc and Mvdc Technologies in Modern Power Grids, Technical Report, Oak Ridge National Laboratory, Oak Ridge TN 2019.

[29] Y. V. Makarov, M. A. Elizondo, J. G. O’Brien, Q. Huang, H. Kirkham, Z. Huang, M. Chinthavali, S. Debnath, N. Mohan, W. Hess, D. Duebner, D. Orser, H. Brown, D. Osborn, J. Feltes, D. Kurthakoti, and W. Zhu, Models and Methods for Assessing the Value of HVDC and MVDC Technologies in Modern Power Grids, Technical Report, Pacific Northwest National Laboratory, Richland, WA, 2017.

[30] S. Debnath, Q. Xia, M. Saeedifard, and Md. Arifujjaman, “Advanced High-Fidelity Lumped EMT Grid Modelling \& Comparison” 2019 CIGRE Grid of the Future (GOTF), 2019.

[31] S. Debnath, A. Foote, O. C. Onar and M. Chinthavali, "Grid Impact Studies from Dynamic Wireless Charging in Smart Automated Highways," 2018 IEEE Transportation Electrification Conference and Expo (ITEC), Long Beach, CA, 2018, pp. 950-955.

[32] B. Xiao et al., "Implementation of system level control and communications in a Hardware-in-theLoop microgrid testbed," 2016 IEEE Power \& Energy Society Innovative Smart Grid Technologies Conference (ISGT), Minneapolis, MN, 2016, pp. 1-5.

[33] H. Xianlai, D. Yunlong, and L. Zhiguo, "Strategy of AC-Isolated Island Detecting and Control Mode Switching over in Zhoushan Project," 13th IET International Conference on AC and DC Power Transmission (ACDC 2017), Manchester, 2017, pp. 1-6.

[34] Z. Fang, J. Lyu, J. Jing, H. Shao, X. Li, and X. Cai, "Research on Real-Time Simulation Modelling of Zhangbei Renewable Energy Base Based on RTDS," 8th Renewable Power Generation Conference (RPG 2019), Shanghai, China, 2019, pp. 1-6.

[35] J. Beerten, S. Cole, and R. Belmans, "Generalized Steady-State VSC MTDC Model for Sequential AC/DC Power Flow Algorithms," IEEE Transactions on Power Systems, vol. 27, no. 2, pp. 821829, May 2012.

[36] Western Electricity Coordinating Council (WECC) Renewable Energy Modeling Task, "WECC Guide for Representation of Photovoltaic Systems In Large-Scale Load Flow Simulations," ForceWestern Electricity Coordinating Council Modeling and Validation Work Group, Aug. 2010.

[37] North American Electric Reliability Company (NERC), Distributed Energy Resource - Connection Modeling and Reliability Considerations, NERC report, Feb. 2017.

[38] Q. Huang and V. Vittal, "Integrated Transmission and Distribution System Power Flow and Dynamic Simulation Using Mixed Three-Sequence/Three-Phase Modeling," IEEE Transactions on Power Systems, vol. 32, no. 5, pp. 3704-3714, Sept. 2017.

[39] North American Electric Reliability Company (NERC) Standard TOP-001-3 - Transmission Operations.

[40] M. J. Reno, J. Deboever, and B. Mather, "Motivation and Requirements for Quasi-Static Time Series (QSTS) for Distribution System Analysis," IEEE Power Electronics General Meeting, Chicago, IL, 2017.

[41] K. P. Schneider, J. C. Fuller, and D. P. Chassin, "Multi-State Load Models for Distribution System Analysis," IEEE Transactions on Power Systems, vol. 26, no. 4, pp. 2425-2433, Nov. 2011.

[42] S. Lu, N. Samaan, D. Meng, F. Chassin, Y. Zhang, B. Vyakaranam, W. Warwick, J. Fuller, R. Diao, T. Nguyen, and C. Jin, Duke Energy Photovoltaic Integration Study: Carolinas Service Areas, Technical Report PNNL-23226, Pacific Northwest National Laboratory, Richland, WA, March 2014. 
[43] X. Ke, N. Samaan, J. Holzer, R. Huang, B. Vyakaranam, M. Vallem, M. Elizondo, N. Lu, X. Zhu, B. Werts, Q. Nguyen, A. Huang, and Y. V. Makarov, "Coordinative Real-Time Sub-Transmission Volt-Var Control for Reactive Power Regulation between Transmission and Distribution Systems," IET Generation, Transmission and Distribution, vol. 13, iss. 11, pp. 2006-2014, 2019.

[44] T. Williams, J. Fuller, K. Schneider, B. Palmintier, B. Lundstrom, and S. Chakraborty, "Examining System-Wide Impacts of Solar PV Control Systems with a Power Hardware-in-the-Loop Platform," 2014 IEEE 40th Photovoltaic Specialist Conference (PVSC), Denver, CO, USA, 2014.

[45] B. Palmintier, B. Lundstrom, S. Chakraborty, T. Williams, K. Schneider, D. Chassin, "A Power Hardware-in-the-Loop Platform With Remote Distribution Circuit Cosimulation," IEEE Transactions on Industrial Electronics, vol. 62, no. 4, pp. 2236-2245, 2015.

[46] A. Gavrilovic, "AC/DC system strength as indicated by short circuit ratios," International Conference on AC and DC Power Transmission, London, UK, 1991, pp. 27-32.

[47] J. W. Feltes ,and B. S. Fernandes, "Wind Turbine Generator Dynamic Performance with Weak Transmission Grids," 2012 IEEE Power and Energy Society General Meeting, San Diego, CA, 2012.

[48] NERC Reliability Guideline-Improvements to Interconnection Requirements for BPS-Connected Inverter-Based Resources, Sept. 2019, https://www.nerc.com/comm/PC_Reliability_Guidelines_DL/Reliability_Guideline_IBR_Intercon nection_Requirements_Improvements.pdf.

[49] Y. Zhang, S. F. Huang, J. Schmall, J. Conto, J. Billo, and E. Rehman, "Evaluating system strength for large-scale wind plant integration," 2014 IEEE Power Electronics General Meeting, Conference, and Exposition, National Harbor, MD, 2014.

[50] NERC Reliability Guideline-Integrating Inverter-Based Resources into Low Short Circuit Strength Systems, Dec. 2017, https://www.nerc.com/comm/PC Reliability Guidelines DL/Item 4a. Integrating\%20 InverterBased Resources into Low Short Circuit Strength Systems - 2017-11-08-FINAL.pdf.

[51] Midcontinent Independent System Operator (MISO), "Renewable Integration Impact Assessment Finding Integration Inflection Points of Increasing Renewable Energy," MISO Third Workshop, RIIA Phase 1\&2 Wrap-Up, Nov. 2019, https://cdn.misoenergy.org/20191115\%20RIIA\%20Workshop\%20Item\%201\&2\%20Operating\%20 Reliability400607.pdf.

[52] Australian Energy Market Operator (AEMO), Transfer Limit Advice-South Australia System Strength, Report for the National Electricity Market, Dec. 2018, https://www.aemo.com.au//media/Files/Electricity/NEM/Security and Reliability/Congestion-Information/2018/TransferLimit-Advice---South-Australian-System-Strength.pdf.

[53] W. Dong, H. Xin, D. Wu, and L. Huang, "Small Signal Stability Analysis of Multi-Infeed Power Electronic Systems Based on Grid Strength Assessment," IEEE Transactions on Power Systems, vol. 34, no. 2, pp. 1393-1403, March 2019.

[54] Opal-RT Technologies, “eHS Specifications," https://www.opal-rt.com/systems-efpgasim/.

[55] Opal-RT Technologies, "Modular Multilevel Converters," https://www.opal-rt.com/modularmultilevel-converter/.

[56] RTDS Technologies, "Modular Multilevel Converters," https://www.rtds.com/applications/hvdcfacts/. 
[57] M. D. Omar Faruque et al., "Real-Time Simulation Technologies for Power Systems Design, Testing, and Analysis," IEEE Power and Energy Technology Systems Journal, vol. 2, no. 2, pp. 63-73, June 2015.

[58] S. Debnath, "Real-Time Simulation of Modular Multilevel Converters," 2018 IEEE Energy Conversion Congress and Exposition (ECCE), Portland, OR, 2018, pp. 5196-5203.

[59] NR Electric, "NR Electric Uses RT-LAB Real-time Simulator to Test the Control and Protection System for Zhoushan Multi-terminal MMC-HVDC Project," https://blob.opalrt.com/medias/L00161 0143.pdf.

[60] Opal-RT Technologies, “Electrical Real-Time Simulation Systems,” https://www.opalrt.com/simulation-systems-overview/.

[61] RTDS Technologies, "Substep: High-Fidelity Simulation and Testing of Power Electronics," https://knowledge.rtds.com/hc/en-us/articles/360034828933.

[62] G. D. Irwin, C. Amarasinghe, N. Kroeker and D. Woodford, "Parallel processing and hybrid simulation for HVDCNSC PSCAD studies," 10th IET International Conference on AC and DC Power Transmission (ACDC 2012), Birmingham, 2012, pp. 1-6.

[63] P. M. Farsani, N. R. Chaudhuri, and R. Majumder, "Hybrid Simulation Platform for VSC-HVDCAssisted Large-Scale System Restoration Studies," 2016 IEEE Power and Energy Society Innovative Smart Grid Technologies Conference (ISGT), Minneapolis, MN, 2016, pp. 1-5.

[64] Opal-RT Technologies, "Experience the Power of HYPERSIM," https://www.opal-rt.com/wpcontent/uploads/2019/01/HYPERSIM Performance and Benchmarks.pdf.

[65] Harshani Konara, U. D. Annakkage, and C. Karawita, "Interfacing Electromagnetic Transient Simulation to Transient Stability model Using a Multi-port Dynamic Phasor Buffer Zone," https://knowledge.rtds.com/hc/en-us/articles/360026329714-Real-Time-ElectromagneticTransient-and-Transient-Stability-Co-Simulation-Model-Using-a-Dynamic-Phasor-Buffer-Zone.

[66] Typhoon HIL Inc., “OpenDSS \& Typhoon HIL Co-simulation,” https://www.typhoonhil.com/documentation/typhoon-hil-application-notes/References/OpenDSS power_flow cosimulation.html.

[67] B. Palmintier, B. Lundstrom, S. Chakraborty, T. Williams, K. Schneider, and D. Chassin, "A Power Hardware-in-the-Loop Platform With Remote Distribution Circuit Cosimulation," IEEE Transactions on Industrial Electronics, vol. 62, no. 4, pp. 2236-2245, April 2015.

[68] US Department of Energy, Office of Electricity, Transformer Resilience and Advanced Components (TRAC), "Solid State Power Substation Technology Roadmap," Oct. 2018.

[69] A. Arif, Z. Wang, J. Wang, B. Mather, H. Bashualdo, and D. Zhao, "Load Modeling-A Review," IEEE Transactions on Smart Grid, vol. 9, no. 6, pp. 5986-5999, Nov. 2018.

[70] North American Electric Reliability Council, “1996 System Disturbances,” Aug. 2002.

[71] L. Pereira, D. Kosterev, P. Mackin, D. Davies, J. Undrill, and W. Zhu, "An Interim Dynamic Induction Motor Model for Stability Studies in the WSCC," IEEE Trans. Power Syst., vol. 17, no. 4, pp. 1108-1115, Nov. 2002.

[72] D. Kosterev, A. Meklin, J. Undrill, B. Lesieutre, W. Price, D. Chassin, R. Bravo, and S. Yang, "Load Modeling in Power System Studies: WECC Progress Update," Proc. IEEE Power Electronics General Meeting, Pittsbugh, PA, 2008, pp. 1-8.

[73] North American Electric Reliability Council, "Reliability Guideline-Parameterization of the DER_A Model," Feb. 2017, 
https://www.nerc.com/comm/PC_Reliability_Guidelines_DL/Reliability_Guideline_DER_A_Para meterization.pdf.

[74] A. Ellis, Y. Kazachkov, E. Muljadi, P. Pourbeik, and J. J. Sanchez-Gasca,, "Description and technical specifications for generic WTG models-A status report.” In 2011 IEEE/PES Power Systems Conference and Exposition (pp. 1-8). IEEE, March 2011.

[75] P. Pourbeik, J. J. Sanchez-Gasca, J. Senthil, J. D. Weber, P. S. Zadehkhost, Y. Kazachkov, and A. Ellis, "Generic Dynamic Models for Modeling Wind Power Plants and Other Renewable Technologies in Large-Scale Power System Studies." IEEE Transactions on Energy Conversion, vol. 32, no. 3, pp. 1108-1116, 2016.

[76] Western Electricity Coordinating Council Renewable Energy Modeling Work Group, "Proposal For New Features for the Renewable Energy System Generic Models."

[77] E. Rehman, M. Miller, J. Schmall, S. H. (Fred) Huang, "Dynamic Stability Assessment of High Penetration of Renewable Generation in the ERCOT Grid," ERCOT, April 2018, http://www.ercot.com/content/wcm/lists/144927/Dynamic Stability_Assessment_of_High_Penetra tion of Renewable Generation in the ERCOT Grid.pdf.

[78] K. P. Schneider, F. K. Tuffner, M. A. Elizondo, J. Hansen, J. C. Fuller, and D. P. Chassin, "Adaptive Dynamic Simulations for Distribution Systems Using Multistate Load Models," IEEE Transactions on Smart Grid, vol. 10, no. 2, pp. 2257-2266, 2019. 



\section{APPENDIX A. GLOSSARY OF TERMS}

1. Time steps is the incremental change in time for which the governing equations are solved

2. Duration of simulation is the virtual time for which the system needs to be simulated

3. No. of states or total no. of states is the states represented in the differential algebraic equations

4. Time taken to simulate is the actual time taken to simulate the system for a given duration of simulation and no. of states

5. No. of states/unit is the states simulated in a single computing unit that could be a central processing unit (CPU) or field programmable gated array (FPGA) or graphic processing unit (GPU)

6. Real-time simulation is the simulation of systems that require synchronization of time-steps with an external clock

7. Virtual/offline simulation is the simulation of systems without any synchronization requirements. The time taken to simulate a given duration of simulation will not be equal to the duration of simulation

8. Faster-than-real-time simulation is the simulation of systems that can be performed faster than the external clock. An example is the online stability assessment tools that require PF or TS or EMT simulations to be completed for several contingencies within defined time intervals (e.g., 1-30 min) 
